\title{
The Austrian path to the constitution of 1 May 1934 - An application of the paradigm of 'Militant Democracy' just avant la lettre!?
}

\begin{abstract}
ALEXANDER BALTHASAR
Visiting Professor of Public Law, Andrássy University, Budapest

ORIGINAL RESEARCH PAPER

Received: February 3, 2020 • Revised manuscript received: November 6, 2020 • Accepted: February 11, 2021 Published online: October 25, 2021

(C) 2021 Akadémiai Kiadó, Budapest

ABSTRACT

This paper seeks to compare the academic model of 'militant democracy' advocated in 1937 by Karl Loewenstein with the real political developments that had taken place only a few years before in Austria, under the responsibility of Engelbert Dollfuß. It further aims to to reveal the 'missing link' between the actions (mere plans included) of - in particular - Catholic political leaders in Germany 1931/1933 (Heinrich Brüning, Franz v. Papen, Heinrich Held), directed at least from 1932 onwards in particular against the rise of the National Socialist movement, well-known both to Loewenstein and Dollfuß. It is argued that Loewenstein's model contains serious theoretical flaws and paves, at least when taken literally, the way to dangerous exaggerations, while the approach of the Dollfuß government was far more balanced. Any assessment of Dollfuß' measures that - as is still the case in Austria - only focuses on the breach of the constitution then in force (the main document being the BundesVerfassungsgesetz, B-VG) as such, without offering a better alternative to prevent the National Socialist danger is unconvincing, not only from a moral, but also, and in particular, from a legal perspective.
\end{abstract}

\section{KEYWORDS}

Karl Loewenstein, Engelbert Dollfus, militant democracy, Austrian constitutional law, national socialism

\section{Preface}

What I am trying here is

\footnotetext{
* Corresponding author. E-mail: alexander.balthasar@andrassyuni.hu

Based on a presentation held at the IVR Congress 2019 in the workshop "The Normative Content of the Principle of Democracy in Central-Europe" chaired by prof. Nora Chronowski.
} 
- to compare the academic model of 'militant democracy' advocated in 1937 by Karl Loewenstein with the real political developments which had taken place, only a few years before, in Austria, under the responsibility of Engelbert Dollfuß;

- to reveal the 'missing link' between both phenomena: the actions (mere plans included) of - in particular - Catholic political leaders in Germany 1931/1933 (Heinrich Brüning, Franz v. Papen, Heinrich Held), directed at least from 1932 onwards in particular against the rise of the NS movement, well-known both to Loewenstein and Dollfuß.

The aim is to show that

- Loewenstein's model contains serious theoretical flaws and paves, at least when taken literally, the way to dangerous exaggerations, while the approach of the Dollfuß government was far more balanced

- an assessment ${ }^{1}$ of Dollfuß' measures which - as is still the case in Austria - only focuses on the breach of the constitution then in force (the main document being the Bundes-Verfassungsgesetz, $\mathrm{B}-\mathrm{VG}$ ) as such, without offering a better alternative to prevent the NS danger is unconvincing, not only from a moral, but also, and in particular, from a legal perspective.

Every focus implies simplification, in particular by emphasizing some aspects while dimming others. So I will disregard here

- general authoritarian tendencies of the time, not only in Austria or Germany, but also in western democracies (which only meant to enhance the efficacy of legislation without barring parts of the electorate from participation $)^{2}$

${ }^{1}$ If Afshin Ellian (2012) $26 \mathrm{f}$ is right, this kind of assessment is rooted in 'Protestant Theology' - a curious finding for a country which had been predominantly Catholic for centuries, although only at first sight; cf. for the relevance of

- the Protestant 'sola-scriptura-principle' in Austrian constitutional law Balthasar (2006) 137 f, 172, fn 794)

- the device 'Catholica non leguntur' also in Austrian academia (Balthasar [2006] 294).

There is, however, some indication of hope: one the one hand, the current president of the Austrian Constitutional Court, Christoph Grabenwarter, stated, only some years ago, in the very first sentence of his foreword to a volume dealing with the relationship between law and necessity (2012) 5: 'Der Staatsnotstand ist der Lackmustest für den Rechtsstaat. Erst im Staatsnotstand erweist es sich, ob sich der Rechtsstaat auch im Zustand existentieller Bedrohung behaupten und bewähren kann' ('the state of emergency is the litmus test for the rule of law. It is only in the state of emergency that we see whether the rule of law is able to stay its ground and prove itself against existential danger; unofficial translation by A.B.). On the other hand, we dispose now of two recent studies revealing the still existing limits of the current Austrian emergency law: Fister (2012) and ALES (2016), comprising also Wiederin (2016).

${ }^{2}$ cf. for western countries and for Germany (during the chancellorship of Heinrich Brüning) Lindseth (2014) $171 \mathrm{f}$, for Austria Hanisch (1994) $302 \mathrm{f}$ (on p 303 Hanisch reports that even the representative of the League of Nations of the time, Rost van Tonningen, had advocated already then and in this capacity 'authoritarian measures'); Ilse Reiter-Zatloukal (2014) $19 \mathrm{f}, 40 \mathrm{f}$ (with regard to the 'Patriotic Guards' ['Heimwehr']), Wohnout (2014) $51 \mathrm{f}, 53$, fn 4 (with regard to the editor-in chief of the 'Furche', medium of the Catholic Party, Friedrich Fun-der), and Jabloner (2014) 99 f, 109 (with regard to ideas in that vein even acceptable to Karl Renner, one of the leading Social Democrats of the time, former head of government and president of the chamber of Deputies of Parliament, see infra section III, lit A/2/b/ba, and lit B/4, fn 284).

In contrast, the experimental application of the famous KWG ('Kriegswirtschaftliches Ermächtigungsgesetz' = Act of 24 July 1917, RGBl Nr 307, adopted still in 'Cisleithania', the 'Austrian' part of the Austrian-Hungarian monarchy, explicitly kept in legal force in the subsequent law of the Austrian Republic by paragraph 7 (2) of the Act of 1 October 1920, BGBl Nr 2, on the transition to the new Constitution and applied several hundred times until 1927, see Hanisch [1994] 305, fn 63) in October 1932 by the Dollfuß government (see Widder [1980] 349 f, 373 f; Wohnout [2014] 52, fn 3) seems to belong already to the given context here (cf. infra text by fn 148). 
- the (Austro-)Marxist interpretation of the actions of the Dollfuß government. ${ }^{3}$

\section{THE PARADIGM OF 'MILITANT DEMOCRACY'}

\subsection{The paradigm}

In 1937, the then (due to discrimination because of his Jewish origin) exiled German constitutional lawyer and (in the USA) political scientist Karl Loewenstein (in Germany: Löwenstein) ${ }^{4}$ published an article ('Militant Democracy and Fundamental Rights') in the American Political Science Review (417 et seq, 638 et seq) where he postulated that, in order to resist rising fascism, 'Democracy must become militant' ${ }^{5}$ Starting from the three premises:

- 'Democracy stands for fundamental rights, for fair play of all opinions, for free speech, assembly, press', ${ }^{6}$, but also for 'legality"7

${ }^{3}$ In that direction I would like to restrict myself to the following: in my opinion it was

- the oversimplified dichotomy of the Communist Manifesto in which the final combatants of the last class struggle are only the 'bourgeoisie' and the 'proletariat' (critical already Bernstein [1923] $63 \mathrm{f}$ ) as well as, consequently,

- the view that the transition period between the dictatorship of the 'bourgeoisie' and the dictatorship of the 'proletariat', the 'democratic republic', could only oscillate between these two poles (cf. Adler [1922] $188 \mathrm{f}$; cf. also Balthasar [2006] $243 \mathrm{f}$ for the meaning of the term 'demokratische Republik' in Austro-Marxist theory) which barred the view of 'Austro-Marxist' Social Democrats (cf., paradigmatically, the speech of Otto Bauer delivered on 10 March 1933 before Social Democrat functionaries in Vienna, cited by Berchtold [1998] 724 f; see also Kreisky [1986/1995] 211 f, and Leser [1988] 52 [emphasis added], who characterized the Social Democrats' attitude to that part of history as a 'constant denial of facts'; for the orthodox Communist 'interpretation' see Reisberg [1974] 3, $159 \mathrm{f}$ ) that

- the formal procedures of egalitarian democracy could also be abused by third parties (as the NS), and, consequently, that

- measures suspending the machinery of the 'democratic republic' were not necessarily directed against the 'proletariat', but could even work also in their interest.

${ }^{4}$ For a biographical survey see, e.g., Lepsius (2015) $411 \mathrm{f}$. See also, and in particular for two preceding contributions of Loewenstein (1935a and 1935b), Cliteur/Rijpkema (2012) $28 \mathrm{f}$.

${ }^{5}$ Cit Loewenstein (1937) 423; see also $430 \mathrm{f}, 638 \mathrm{f}, 657$ ('militant will for self-preservation'). Is it too far-fetched to pick out of this term an allusion to

- the 'ecclesia militans' (a notion most probably coined in the $12^{\text {th }}$ century and thus during the era of the crusades by the Cistercian monk Alanus ab Insulis)

- the victories of ancient Hellas at Marathon, Plataiai and Salamis over the repeated attempts of the Persian Grand King to subjugate the Greeks, which would have amounted to bringing to an end Greek autonomy and (early) democracy?

If this impression were true (and it is not in the least unlikely that Loewenstein became very well acquainted with both references when being educated in Catholic Munich, attending a humanist secondary school ['Wilhelmsgymnasium', with Latin and ancient Greek still today as obligatory languages]), Loewenstein would have in fact equated European 'fascists' (i.e., after all, still parts of the European population!) with nothing less than Europe's most prominent archenemies (ancient oriental despots as well as medieval oriental Muslims).

${ }^{6}$ Cit Loewenstein (1937) $430 \mathrm{f}$; see, with regard to the 'free play of public opinion', also 424.

${ }^{7}$ Cit Loewenstein (1937) 424. 
- 'Democracy and democratic tolerance have been used' 'for their own destruction' by 'fascist' movements (apparently understood in a broad sense, thus including in particular German 'National-Socialism') ${ }^{8}$

- 'Fascism has declared war on democracy',

Loewenstein recommended 'checking' fascism 'by a similar technique'10 (!), 'by adopting autocratic methods ${ }^{11}$, by 'taking a vacation of legality ${ }^{\text {'12 }}$, in short: 'to forbid the enemies of its' (i.e. Democracy's) 'very existence the use of democratic instrumentalities'. ${ }^{13}$ The main reasoning runs as follows:

'Constitutional scruples can no longer restrain from restrictions on democratic fundamentals, for the sake of ultimately preserving these fundamentals. The liberal-democratic order reckons with normal times. The guarantee of individual and collective rights serves as a legal basis for compromise between interests which ... may fall into conflict, but which nevertheless are animated by common loyalty toward the fundamentals of government. Constitutions are dynamic to the extent that they allow for peaceful change by regular methods, but they have to be stiffened and hardened when confronted by movements intent upon their destruction. Where fundamental rights are institutionalized, their temporary suspension is justified. When the ordinary channels of legislation are blocked by obstruction and sabotage, the democratic state uses the emergency powers of enabling legislation which implicitly, if not explicitly, are involved in the very notion of government. Government is intended for governing. Fascism has declared war on democracy. a virtual state of siege confronts European democracies. State of siege means, even under democratic constitutions, concentration of powers in the hands of the government and suspension of fundamental rights. If democracy believes in the superiority of its absolute values over the opportunistic platitudes of fascism, it must live up to the demands of the hour, and every possible effort must be made to rescue it, even at the risk and cost of violating fundamental principles. ${ }^{, 14}$

\subsection{Assessment}

Although, at first sight, it sounds only too natural to secure one's own self-preservation against 'enemies' by all necessary means, already at second sight we realize serious flaws: two of Loewenstein's three premises are highly problematic, whereas the third is significantly incomplete. Hence, also the conclusions might deserve caution:

\footnotetext{
${ }^{8}$ Cit Loewenstein (1937) 423. On next page (424) we read in the same vein: 'the mechanism of democracy is the Trojan horse by which the enemy enters the city.'

${ }^{9}$ Cit Loewenstein (1937) 432.

${ }^{10}$ Cit Loewenstein (1937) 430.

${ }^{11}$ Cit Loewenstein (1937) 432.

${ }^{12}$ In Loewenstein (1937) 432, the literal quotation runs: 'During war, Léon Blum observes, legality takes a vacation' (this thought is obviously already borrowed from the medieval Canon Law theorem 'necessitas non habet legem').

${ }^{13}$ Cit Loewenstein (1937) 424.

${ }^{14}$ Cit Loewenstein (1937) 432.
} 


\subsubsection{Discussion of the premises.}

- Loewenstein uses a concept of 'democracy' stressing only the deliberative aspects and the limits set out for democracy by the rule of law ${ }^{15}$, while completely neglecting egalitarian participation $^{16}$ and people's sovereignty. ${ }^{17}$

- Apparently the second premise is drawn only from the German example ${ }^{18}$ and, at least in a strict sense, not even true there ${ }^{19}$ (albeit claimed by Adolf Hitler's minister ${ }^{20}$

${ }^{15}$ In Austria, Loewenstein's criteria had already been satisfied by the Fundamental Rights Act ('Staatsgrundgesetz über die allgemeinen Rechte der Staatsbürger') of 21 December 1867, RGBl No 142 - hence at a time when one could seriously assess that the State recognized the rule of law, but certainly did not contain any democratic element. That this finding is not at all a misinterpretation or a malicious insinuation is underlined by the fact that Loewenstein (in the context of advocating for the compatibility of democracy with capitalism, see next fn) explicitly mentions 'the risks arising from universal suffrage'! (cit Loewenstein [1937] 422, emphasis added) and was perfectly ready to think of alternatives (cf. Hacke [2018] 252).

${ }^{16}$ Most remarkably, Loewenstein is eager to assure that democracy is more compatible with capitalism than fascist or 'authoritarian' regimes, going so far as formulating: 'Private capitalism cannot have failed to understand that ... capital controlling democracy is far preferable to corporative middle-class bureaucracy controlling capitalism' (!!; cit Loewenstein [1937] 422, emphasis added). Presuming that 'middle-class bureaucracy' is, at least when compared with 'capitalists', economically considerably poor, Loewenstein - himself son of a manufacturer and, thus, of a 'capitalist' seems to favour an outspoken elitist ('liberal') model of 'democracy' (see previous fn) close to that of Walter Lippmann and others (cf. for this line of American thinking of the time e.g. Weaver/Motion/Roper [2006] $7 \mathrm{f}, 8 \mathrm{f}$ ).

${ }^{17}$ For the relevance of this omission see infra subsection 2/a.

${ }^{18} \mathrm{cf}$. Loewenstein (1937) $426 \mathrm{f}$.

${ }^{19}$ Firstly, Hitler was not directly elected to power by democratic procedures, but had lost the presidential elections in early 1932 where the former field marshal Paul v. Hindenburg was re-elected as National President ('Reichspräsident'); so Hitler was only appointed as head of government ('Reichskanzler') on 30 January 1933 by President Hindenburg. Moreover, Hitler's party had not only lost about 4\% in the 6 November 1932 elections for the National Parliament ('Reichstag') compared with those of 31 July 1932, but also the newly formed coalition government had, at that time, not yet had its own majority in the National Parliament, so that this Parliament was again immediately dissolved by President Hindenburg after Hitler's appointment (on 1 February 1933, for the legality as well as for the democratic legitimacy of this approach see Jung [1995] 6 f).

Secondly: Although it was the National Parliament which adopted the conferral of ordinary legislation (for four years) to the national government ('Reichsregierung') headed by Hitler ('Gesetz zur Behebung der Not von Volk und Reich' of 24 March 1933, Official National Law Gazette [Reichsgesetzblatt - RGBl] I S 125) the democratic legitimacy already of this Parliament elected on 5 March 1933 - and, therefore, also of this crucial Act as such-may be disputed due to the effects the Emergency Ordinance issued by the National President Hindenburg on 28 February 1933 ('zum Schutz von Volk und Staat') had had on the elections as well as on the formation of the will of members of that Parliament (see in more detail infra section II/D). Obviously, this reservation is still more valid with regard to the second crucial pillar of transformation of the State of Weimar into the NS-State, the Act of 30 January 1934 (the first anniversary of Hitler's appointment to head of the national government), RGBl I p 75, 'über den Neuaufbau des Reichs', which enabled, in its Article 4, the national government also to amend the Constitution (in every respect and without any time limit!), because this Act (see Jung [1995] 59) was already adopted by an again new National Parliament 'elected' on 12 November 1933 where, after dissolution or abolition of all political parties except that of Hitler's NSDAP, no democratic competition at all had been allowed any more (cf. Jung [1995] $36 \mathrm{f}, 42 \mathrm{f}, 52 \mathrm{f}$ ).

Thirdly: when in August 1934 a referendum (not an election!) was held to confirm Hitler's rise to the position of head of State effected by the National Act of 1 August 1934, RGBl I p 747, it was precisely this referendum which was, measured against the yardstick of an already totalitarian régime, a failure (see Jung [1995] $61 \mathrm{f}, 74 \mathrm{f}, 82$ ).

${ }^{20}$ Given his official title ('Minister für Volksaufklärung und Propaganda') in principle all his enunciations (but certainly all the official or public ones) should be treated with caution in order not to be still caught - even decades later - by the trap of this 'propaganda'. 
Joseph Goebbels ${ }^{21}$ ), not to speak of any other European country of that time ${ }^{22}$, whereas

- the third statement is obviously correct, although likewise obviously incomplete, ignoring all the other 'wars' conducted by 'Fascism' against e.g. Communism or, at least by German 'National-Socialism', and even with more furor, against religions (in particular against the Roman-Catholic Church) or, here amounting to the very attempt at annihilation, against races (in particular against Jews ${ }^{23}$ and Gypsies) or other 'social groups' (such as the mentally disabled or homosexuals).

\subsubsection{Discussion of the conclusions}

1.2.2.1. The problem of the 'pouvoir constituant"24. At least in a secular world a (fullyfledged) 'constitution' is a set of rules which has to be created by some human beings, arrogating themselves sovereign power at a certain point in time with regard to a certain number of human

${ }^{21}$ 'Wenn unsere Gegner sagen: Ja, wir haben Euch doch früher die [...] Freiheit der Meinung zugebilligt -, ja, Ihr uns, das ist doch kein Beweis, daß wir das Euch auch tuen sollen! [...] Daß Ihr das uns gegeben habt, - das ist ja ein Beweis dafür, wie dumm Ihr seid!' (speech of 4 December 1935: 'That our enemies claim that they did grant us freedom of speech - that does not show that we should grant you the same, but only, how stupid you are' [unofficial translation by A.B.]: see Heiber [1971] 272; see also Bracher [1964] 375, in particular the quotations mentioned in fns $39 \mathrm{f}$ ). See also, for a similar quotation of Goebbels, Bracher/Sauer/Schulz (1960), 21, fn 35, and, for Hitler's claim that he was called to power by a 'revolution' enacted by 'the' German people, Jung (1995) $13 \mathrm{f}, 16 \mathrm{f}$.

${ }^{22}$ Neither in Italy nor in Hungary nor in Turkey nor in Spain nor in any other country mentioned (see Loewenstein [1937] 417) by Loewenstein (Austria, Bulgaria, Portugal, Greece, Rumania, Yugoslavia, Latvia, Lithuania, Poland) did the fascist or 'authoritarian' régime rise to power by purely democratic means. When looking more closely, this finding also applies with regard to the transition to Communist rule: neither in Russia in 'October' 1917 did the 'Bolshevists' (despite the meaning of this term!) come into power by a majority based on universal suffrage, nor in the Central and Eastern European countries after World War II, nor in Afghanistan 1978: everywhere an additional element of violence was needed: in St Petersburg the so-called 'storming of the Winter Palace', in Central and Eastern Europe and Afghanistan the presence of the Red Army and the support granted to local communists by the Soviet-Union.

${ }^{23}$ Even as early as 1937 this declaration of 'war' against Jews could not only have been perceived, but was of course perceived by Loewenstein, who had suffered the consequences of this persecution personally. This is one of the elements of his text where we have to be aware that there is - to use the words of Martin Heidegger (1954) 5 - 'Unsaid' behind the 'Said' or, to put it differently and underlining what was already mentioned supra in fns 15 et 16: Loewenstein's concept of 'democracy' seems to be much more a cipher for a state where there is no discrimination/persecution/annihilation of humans on racial grounds than a 'democracy' in the political meaning of the term (and indeed, at the very end of the second part of his article $[657 \mathrm{f}]$, Loewenstein reveals his vision: ' $\ldots$ democracy has to be redefined. It should be - at least ... until a better social adjustment ... has been accomplished - the application of disciplined authority, by liberal-minded men, for the ultimate ends of liberal government: human dignity and freedom'.

${ }^{24}$ The arguments put forward here apply also to the form of 'militant democracy' advocated for by another scholar, and a contemporary of Loewenstein, George van den Bergh (see Cliteur/Rijpkema [2012] 229, 240 f, 256 f). In contrast, Hong (2012), $329 \mathrm{f}, 364 \mathrm{f}$ accepts that 'militant democracy' could not, without self-contradiction, be based on an understanding of 'democracy' as 'popular self-legislation', but holds that an alternative understanding (as 'legislative selfrestraint') would serve the purpose; Hong fails, however, to show why his understanding should be exempt from negation by people's ('popular') sovereignty. The same argument applies also to the current German understanding of 'militant democracy' (cf. Thiel [2012] $273 \mathrm{f}$, who admits that no future German pouvoir constituant could be bound by this understanding [293], but focuses only on an 'upheaval', thus neglecting completely the path outlined by Article 146 of the German Fundamental Law [Grundgesetz - GG], where e.g. a Constitutional Assembly could assume 'sovereign dictatorship' - cf. Schmitt [1928a] 237 f). 
(but also legal) individuals, their property and, nowadays as a rule almost without any exception, to a certain territory.

While some sovereigns are easily identifiable - this is in particular the case if this power is considered to reside only in one person, the 'autocrator' ${ }^{25}$ or monarch ${ }^{26}$, but also in a society where the 'nation' is deemed to consist only of a few aristocrats (like in the former Hungary or Poland) where it is clear that at least assuming the competence of changing the constitution by ordinary people can only be illegitimate (from the perspective of the acting sovereign) - it is extremely difficult to distinguish in a state based on people's sovereignty between acts of members of the people which are simply against the constitution still in force (and, therefore, illegal) and (the preparation of) a new articulation of the sovereign ${ }^{27}$ who

- can not only never be bound by one of his previous temporary products ${ }^{28}$, but is

- always (thus not only when just delivering a new product) present in his own State. ${ }^{29}$

Hence, not even deviations from the concept of 'peaceful change by regular methods' and lack of 'loyalty to the fundamentals' of the current constitution can bar outright the voice of the people in its capacity as sovereign.

If, however, this 'voice of the people' is not unanimous, the question might arise as to who (which part of the people) is entitled to exercise this sovereign power? Whereas, still in the $16^{\text {th }}$ and the first half of the $17^{\text {th }}$ century, the answer to this question was quite commonly (e.g. in Germany, France and England) found only through civil war (the solution apparently again put forward by Loewenstein ${ }^{30}$ ), classical Natural Law of the second half of the $17^{\text {th }} / 18^{\text {th }}$

${ }^{25}$ For Immanuel Kant, only the 'autocrator' (the traditional title of the Russian Czar) was the sovereign, owning all power (see [2009] \$51).

${ }^{26}$ It was precisely in this capacity that the Austrian emperor Francis Joseph twice suspended a constitution (1851 and 1865) - although in the end (1867) this was successfully contested by Hungary - thus making use of his double role as not only a 'pouvoir constitué' by the Constitution but also as the 'pouvoir constituant', i.e. the Source of the constitution (cf. for this category Schmitt [1928a] 236). This sovereign position can be perceived as being rooted in a 'pactum subiectionis' (see infra fn 35).

${ }^{27}$ cf. Schmitt (1928b) $82 \mathrm{f}$.

${ }^{28}$ See Böckenförde (1991) 90 f, 99 f; Schmitt (1928b) 83; Anschütz (1933) 1 ff; VfGH 30 June 1949, B 299/48, VfSlg 1827.

${ }^{29} \mathrm{I}$ am definitely not of the opinion that 'Sovereignty as a political category occurs' only 'during a crisis or menace', whereas 'in all other periods the sovereign is nothing other than an untraceable notion' (!) 'that occasionally happens to appear as a mist at the edge of a legal order' (cit Ellian [2012] 64, emphasis added - a position which, according to the author's own assessment, resembles 'Protestant theology', see supra fn 1); rather, in my view (cf. Balthasar [2006] 70, fn 292 ) it is only the continued affirmation of the Sovereign which provides the basis for the validity of the current law.

${ }^{30} \mathrm{cf}$. the last sentences of the quotation cited supra in lit A. Keeping in mind that Loewenstein himself had to emigrate it is, at least from an empathetical perspective, quite understandable that (against the background of what he had lost) he would have preferred to have had the opportunity to stand his ground in Germany, and we may also admit that the costs of even a civil war in Germany in 1933 would have been far lower than what was eventually needed to defeat the NS regime in World War II. Nevertheless, the singularity of the NS is a strong argument not to generalize (as was indeed done by Loewenstein's formulae applying not only to monstrosities). 
century contested the Aristotelian premiss that 'the people' ${ }^{31}$ is an inevitable entity prior to the individual ${ }^{32}$, which has to remain together in any circumstance, thus opening up the less bloody alternative that those parts overruled by the dominant part $(s)^{33}$ terminate the underlying Social Contract (or, more precisely, do not consent to the modified version after termination of the old one by the majority) by making use of their inherent natural right to secession $^{34}$, hence invoking 'sovereignty' (in the fullest meaning of the $\operatorname{term}^{35}$ ) also for themselves. $^{36}$

1.2.2.2. 'Democratic fundamentals' beyond human grasp?. Now it is true that Loewenstein - in the article here at issue ${ }^{37}$ - did not in the least refer to people's sovereignty. This omission, however, as such does not solve the problem. Of course it is possible to presuppose an ultimate non-secular source of the 'Constitution' or of the 'democratic fundamentals'. In this case,

${ }^{31}$ Aristoteles (see next fn) used the word ' $\pi$ ó $\lambda \iota \varsigma$ ' which corresponds to the Roman 'populus', but should obviously not be equated with ' $\varepsilon$ ' $\theta$ vos'.

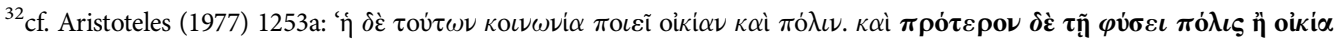

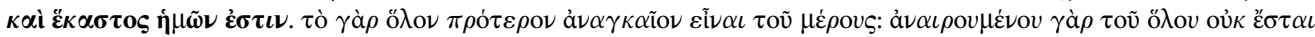

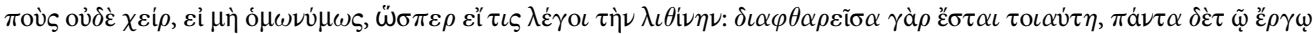

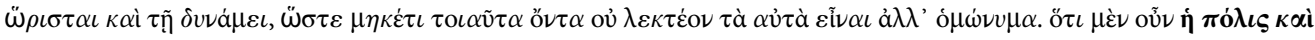

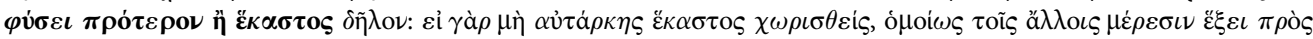

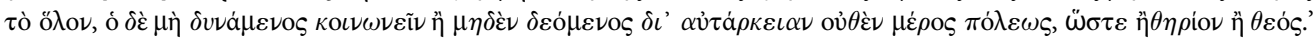
This position was again taken - while explicitly rejecting the theory of Social Contract - by Marxists (cf. Adler [1922] 31, 69, in fn 1 referring to his terms 'Sozial-a-priori' and 'Transzendentalsoziales').

${ }^{33} \mathrm{~A}$ majority as such is no argument at this stage, cf. Isensee (1995) 86.

${ }^{34} \mathrm{cf}$. the common Article 1 of the ICCPR and of the ICESCR, respectively, completed by Articles 2 (1), 12 (1) and (4) ICCPR, showing however, that (individual or even collective) 'secession' is a right of the minority, not an option for the majority to get rid of the minority.

${ }^{35}$ The 'Social Contract' may (inspired by Samuel v. Pufendorf, cf. Isensee [1995] $87 \mathrm{f}$ ) be further structured in

- the original will of individuals to form a 'people' (the 'pactum unionis' (cf. Locke [1960/1965/2008] VIII/\$\$ 95 f; Achenwall/Pütter [1995] \$655),

- the subsequent fundamenal decisions as to

○ how they should be governed (decision on the 'forma regiminis', i.e. abiding by the rule of law or despotically, cf. Kant [2011] 352)

o who is to govern (decision on the 'forma imperii', cf. Kant, ib) -

- an even less developed form of these decisions (ii) being the 'pactum subiectionis' (cf. Hobbes [1968/1980] Chapter XVII: 'Commonwealth by Institution', with only one limitation [ineffectiveness, see Chapter XXI; cf. infra, fn 42); Locke [1960/1965/2008] Chapters X and XI/\$\$ $132 \mathrm{f}$, stating that 'absolute arbitrary power' could never 'be supposed' to have been conferred; Achenwall/Pütter [1995] $\$ 656$ - for limitations see $\$ \$ 669 \mathrm{f}$ ),

and only on this basis eventually in

- the specific constitution.

Obviously, among these steps dissolving the 'pactum unionis' is the most fundamental exercise of 'sovereignty'.

${ }^{36} \mathrm{On}$ an individual basis this right to 'secession' (understood also as a means of legitimate resistance) has always taken the form of a 'ius emigrandi' (cf. Balthasar [2017] $214 \mathrm{f}, 235 \mathrm{f}$, fns $180 \mathrm{f}$ ).

${ }^{37}$ Loewenstein must have been completely aware of the implications of this notion, given that he had, 15 years ago, published a book on the founder of the theory of people's pouvoir constituant, Emmanuel Sieyès (see Böckenförde [1991] $94 \mathrm{f}$, fn 9). 
however, prudence advises us to restrict this sphere of 'fundamental principles', i.e. of 'absolute values' which are protected from every (even the most peaceful) attempt to change them to those core elements which can credibly be assumed as really transcending space and time and, thus, as truly 'universal' and 'inalienable', being withheld from any legitimate human interference, even by a human Sovereign.

Otherwise rapidly changing circumstances will enforce multiple rapid changes of opinion as to the exact content of these 'fundamentals' and, thus, reduce the concept of 'inalienability' (or, even if some changes of divine revelation from time to time are taken into account, at least divine dignity) ad absurdum.

And indeed there is some indication ${ }^{38}$ that Loewenstein did, when referring to 'absolute values' worth being protected by 'every possible effort', really only mean - as a deeper meaning concealed beneath the surface term 'democracy' - what we now label 'human dignity', in the individual as well as in the collective dimension of this term. This interpretation would also coincide with the currently prevailing understanding of his concept not so much in the field of 'democracy' as a political form of government, but in that of 'human rights'. ${ }^{39}$

1.2.2.3. Is self-preservation really an 'absolute' value?. When restricted in this way, however, another problem ${ }^{40}$ arises: if 'human dignity' is really the supreme ('absolute') value to be preserved at all costs from 'fascist' attack and, as such, 'universal' and 'inalienable', then

\footnotetext{
${ }^{38}$ See supra fn 23.

${ }^{39}$ cf., paradigmatically, Article 30 UDHR. The application of this idea, however, also to the sphere of 'fundamental rights' - despite the fact that the difference between universal 'human' and mutuable 'fundamental' rights had already been made visible decades ago in sections (2) and (3) of Article 1 the German Fundamental Law (GG), respectively (cf., however, also Articles 2, 3 (5), 21 (1) TEU where the term 'human rights' is used, in contrast to the CFR; see in more detail Balthasar/Pichler [2014] $93 \mathrm{f}, 97 \mathrm{f}$ ) - is highly problematic:

An attempt as stated in Article 54 of the EU Charter of FundamentalRights to deny 'the right to engage in any activity or to perform any act aimed at the destruction of the rights and freedoms recognised in this Charter or at their limitation to a greater extent than is provided for herein' is only legitimate insofar as also all these rights are considered not to be human creations, but to stem all and in all their current elements from 'natural law' (cf. for such a position indeed Borowsky [2014] point 9). Taken literally Article 54 CFR now impedes not only institutionally fully legitimate activities for, e.g. the abolition of Article 6 (1) TEU, but even any application for termination of membership of the EU under Article 50 TEU (because such a step implies, too, at least a future territorial 'limitation' of Charter rights and freedoms, as was indeed at least partly the intention of Brexit!). It is really alarming (showing the growing fragmentation between institutional and human rights law) that neither the Charter Convention nor, later on, e.g. Wood (2014) 1539 f) nor Bezemek (2019), in particular point 3, have realized this excessive effect on the future exercising of legislative powers by means of a human-made fundamental rights provision, the danger of which may be illustrated by the hint that, strictly speaking, not even the publication of this footnote is covered by Article 13 of the Charter. cf., however, Hoppe (2019), points 12, 27, 39, 43.

${ }^{40}$ The problem as such is addressed, but not solved in the contribution of Cliteur/Rijpkema (2012) $265 \mathrm{f}, 266$ (dealing with their third, 'civil rights' centered meaning of 'militant democracy').
} 
this value applies, at least in principle, also to the 'fascist' 'enemy' (not only to the 'inimicus', but also to the 'hostis ${ }^{41}$ ). Measures for self-preservation may of course be taken ${ }^{42}$, but not 'at all costs ${ }^{33}$, i.e.

- not in simply applying the 'ius talionis' (and of course not, as suggested by Loewenstein's concept, already preventively applying the 'enemy's' methods!),

- even not in only a strictly proportionate ${ }^{44}$ manner (i.e. limited to what is really needed to overcome the danger),

- but in addition also unilaterally refraining in all circumstances from intrinsically inhuman action. $^{45}$

These principles applying even in most extreme situations (if the 'enemy' should aim to annihilate one-self) they have to be respected - flowing from the principle of reciprocity or equality - the more so in less clear situations, thus also taking into account the degree of legitimacy which might underlay the 'enemy's' position (or that of a third person ${ }^{46}$ ). It is exactly

\footnotetext{
${ }^{41}$ See, for this difference Schmitt (1963) 29.

${ }^{42} \mathrm{cf}$. not only Article 51 UNC (the application of which, however, is restricted to 'attacks ... imputable to a foreign State', cit ICJ [2004] point 139]), but also the corresponding 'state of necessity .... recognized in customary international law' (cit ICJ, ib, point 140, referring in particular to Article 25 of the ILC 'Articles on Responsibility of States for Internationally Wrongful Acts'; see in this respect also Molier [2012] 187 f), but also Article 4 ICCPR or Article 15 ECHR (where the 'life of the nation' is explicitly stated as the overriding value). See also Heintze (2012). It may, however, very well be that
}

- even this current international setting will turn out to be too narrowly construed (cf. the views referred to by Randelzhofer/Nolte [2012] points 8, 11, 13, 36, 37 [fn 137], $51 \mathrm{f} ; \mathrm{cf}$. also, for the ECHR, Balthasar [2006] 659), but that in particular

- our modern written national constitutions (see, for the Austrian constitution, supra fn 1 and infra fns 211, 214, for the German constitution Thiel [2012] $297 \mathrm{f}$ ) have, more often than not, failed to state this not only traditional (cf. Molier [2012] $184 \mathrm{f}$ ), but self-evident finding in a way which also allows positivists to accept it.

From a natural law point of view one would assume that such a provision must be enshrined, if not in the respective constitution, then at any rate in the underlying Social Contract (see supra fn 35), as a necessary corollary (pre-condition) to the task of a State to grant protection (cf. for this task:

- Hobbes [1968/1980] Chapter XXI ('The end of Obedience is Protection ...'); Locke [1960/1965/2008] Chapter XI, $\$ 134$ ('The great end of Men entring into Society, being the enjoyment of their Properties in Peace and Safety ...')

- Article 2 of the French Declaration of Human and Citizens' Rights of 5 October 1789, which still forms part of the current French constitution, running: 'Le but de toute association politique est la conservation des droits naturels et imprescriptibles de l'Homme. Ces droits sont la liberté, la propriété, la sûreté, et la résistance à l'oppression.'

- Article 56 read in conjunction with Article 55 lit c UNC; Article 1 ECHR; Article 2 ICCPR; Article 2 ICESCR.

${ }^{43}$ Cit ECtHR 22 March 2001, Streletz, Kessler, Krenz/G, points 71 f; while the principle is obviously correct, the specific application may be disputed, cf. Balthasar (2017) 233, fn 161.

${ }^{44} \mathrm{cf}$, paradigmatically, Article 31 (1) (c) and (d) of the Rome Statute of the International Criminal Court; Borowsky (2014) point 10, also emphasized this limitation.

${ }^{45} \mathrm{cf}$, paradigmatically, Article 33 (2) of the Rome Statute, Article 10 (1) of the ICCPR or the non-derogability of Article 3 ECHR.

${ }^{46}$ As the Appeals Chamber of the ITY stated in its Judgement of 7 October 1997 (IT-96-22-A, Erdemovic), point 19, even 'duress does not afford a complete defence to a soldier charged with a crime against humanity and/or a war crime involving the killing of innocent human beings.' 
this negation of the principle 'my country, right or wrong' inherent even in legal concepts as a 'state of emergency' or 'self-defence 47 which prevents 'civilized countries' (in the meaning of Article 38 (1) (c) of the Statute of the ICJ or of Article 7 (2) of the ECHR) governed by the 'rule of law' (in the meaning of, e.g., Article 2 TEU or Article 3 SCE) from slipping into the fullyfledged relativism and subjectivism expressed

- already by 'Louis-Antoine-Léon de Saint-Just, the 'Archangel of Terror' in the dark times of the French Revolution' ('No freedom for the enemies of freedom!') ${ }^{48}$

${ }^{47} \mathrm{cf}$. ICJ (2004) point 140; Randelzhofer/Nolte (2012) points $57 \mathrm{f}$. Given the original German academic background of Loewenstein as a lawyer it is striking that he did not make any use of a juridical argument. Did he - forced to change discipline in the USA (see Lepsius [2015] $431 \mathrm{f}$ ) - think that reference to European law concepts would not pay outside the European legal community and in particular not in the USA? Or could Loewenstein then having been of the opinion that Hitler's obvious abuse of these legal terms, in particular in the National Government's Act - based on the 'Enabling Act' of 24 March 1933 (see supra fn 19) - of 3 July 1934, RGBl I p. 529, which bluntly stated that 'all the actions taken on 30 June and 1/2 July 1934 to suppress treason' (i.e. the extra-legal killings - not by any means limited to the killing of Ernst Röhm and of his comrades, but also, e.g., of Kurt v. Schleicher [see infra text by fns 99 and 100], his former deputy in the ministry for defence, major-general Ferdinand v. Bredow, Gustav v. Kahr [see infra subsection 2.3], of Edgar Jung, a secretary of Franz v. Papen [see infra subsection 2.1.3] and other prominent Catholics, see Jung [1995] $71 \mathrm{f}, \mathrm{fn} 40$ ) 'are legal due to the State's self-defence' and which had been eloquently justified by Carl Schmitt ([1934] 945 f; see Quaritsch [1989], 80 f]) had spoiled (contaminated) these terms/arguments/concepts?

${ }^{48}$ Cit Thiel (2012) 276. Likewise, also the still popular formula 'no tolerance for intolerance' (cf. Popper [2003], 361 f, only recently favoured again by the former German Federal President Hans-Joachim Gauck [see Der Spiegel [2019] 'Wir müssen lernen, mutiger intolerant zu sein', 15. 6. 2019: 'Toleranz enthält das Gebot zur Intoleranz gegenüber Intoleranten']) is highly misleading, due to the lack of any objective yardstick.

- taken literally, the formula allows us to negate any right to anyone who dares not to agree with one's own position hence, the crucial question is not the substance of the positions but the role taken: that one who sets the position forces the other either to accept or to oppose it - in the latter case this opposition can be denounced as 'intolerance' and safely be oppressed (this is, nowadays, exactly the way the attribution of the label 'islamophobia' works, cf. Weinberger - former Austrian ambassador in Tunis - [2020]).

- In a more refined sense the formula reminds one of the insight of Thomas Hobbes that the state of nature is a state of 'bellum omnium contra omnes' (cf. Hobbes [1968/1980] Chapter XIII: 'warre . . of every man, against every man') which can only be overcome by a synallagmatic agreement (cf. id, ib, Chapter XIV for the 'second Law of Nature', which seems to be the 'pactum unionis' [see supra fn 35] replacing war with peace; cf. also Kant [2011] $348 \mathrm{f}$ [ed of the Ac]). Even there, however, 'tolerance' can only mean mutual respect for one's own affairs ('property' in the meaning of John Locke, i.e. 'Lives, Liberties, Estates', cit Locke [1960/1965/2008] Chapter IX/\$123, or of Article 2 of the French Declaration 1789 [see supra fn 42]), providing no solution for how to deal with common affairs.

- Hence, what is really required instead of simply outlawing 'intolerants' (which was indeed advocated by Popper, $i b$, 362 ) is to insist on universal respect for the law (understood in a substantive as well as in a procedural sense). If need be, this respect has also to be enforced - but this enforcement does not trigger the 'outlawing' of the perpetrator, nor does it need a 'tolerant' internal (moral) attitude (on the - minoritarian or even majoritarian - side opposing a given position), but only that everyone abides by the law (in foro externo). See also infra section IV/B).

- It was, however, already observed that in particular the German term 'Gewalt' applies likewise to 'potestas' and to purely arbitrary/otherwise illegitimate 'violentia' (see Ernst, [1980] $191 \mathrm{f}$ ). Given that Loewenstein as well as Popper were both German native speakers, this ambiguity of their mother language may have influenced (and misled) the thinking of both. 
- in the well-known dichotomy of 'Freund' and 'Feind' coined and presented as the ultimate principle of politics by Carl Schmitt ${ }^{49}$ only a few years before Loewenstein's article here at issue was published ${ }^{50}$ and, thus assimilating to the 'enemy' (arg: applying a 'similar technique') loosening any objective justification to resist to the 'enemy's' attack $^{51}$

- also in Bolshevist reasoning of the time ${ }^{52}$ - a perhaps even more disturbing ${ }^{53}$ similarity. ${ }^{54}$

\begin{abstract}
${ }^{49}$ See, in particular, Schmitt (1963) $26 \mathrm{f}$. For a proper assessment of this dichotomy in the context of Schmitt's doctrine one has, however, to keep in mind that Schmitt had, even at precisely the same time as he published the first version of the said booklet, also been of the opinion that even in a state of emergency only some constitutional provisions, not, however, the essence of the constitution itself could legally be suspended (cf. Schmitt [1928b], 26) which implied for a state committed to the rule of law, inter alia, the restriction to keep the essence of fundamental rights even in extraordinary situations (cf. ib, 27). This line of thinking fits very well with his earlier work on the institution of 'dictatorship', in particular his differentiation between 'commissarial' and 'sovereign' dictatorship (cf. Schmitt [1928a] 25 f, 130 f, 236 f, even appreciated by Max Adler [1922] $193 \mathrm{fl)} \mathrm{-} \mathrm{according} \mathrm{to} \mathrm{which} \mathrm{only} \mathrm{the} \mathrm{latter} \mathrm{is}$ equivalent to the 'pouvoir constituant', whereas the former is deemed to re-establish, though by extraordinary means, a prespecified, though temporarily perturbed order (this goal also sets limits to the choice of the appropriate means, in particular, if the envisaged order to be re-established is the rule of law). Hence, although it might be that the dichotomy position is the product of a 'sharpening' (cf. Quaritsch [1989] $29 \mathrm{f}$ ), where the 'commissarial dictatorship' was lost, I am more inclined to presume that there is no contradiction at all, meaning that the famous dichotomy just describes, from a purely theoretical point of view (as already in his earliest work on this issue: Political Theology 1921]), very fundamental phenomena not to be presumed in internal conflicts and certainly not to be understood in a normative way (cf. for such an understanding, already Böckenförde [2006] 344 f, 345; cf. also Ellian, [2012] 25 f, 41).
\end{abstract}

${ }^{50}$ The original version of 'Der Begriff des Politischen' was published in 1927 (cf. Quaritsch [1989] 11), the text of the second edition (used here) in 1932 (see supra fn 41). This conceptual closeness of Loewenstein and Schmitt's dichotomy (cf. also Schupmann [2017] 204, in particular fn 1) - and, furthermore, of Loewenstein and the Presidential Ordinance of 28 February 1933 singling out specific enemies (see infra fn 127) - is striking against the background that it was apparently in particular Loewenstein who pushed for Schmitt's prosecution by US occupation forces after World War II (see Mehring [2009] 442).

${ }^{51}$ Even Lenin was still in 1917/18 eager to point out the difference between previous suppression of the exploitedclasses by the ruling ('capitalist') classes and the 'dictatorship of the proletariat' destined to prepare the end of all suppression (cf. Lenin [2012] 99 f, in particular 104; quite similar also Otto Bauer, see Reiter-Zatlouka [2014] 31).

${ }^{52}$ Strongly criticized by Eduard Bernstein (as 'barbarous' and 'most extreme terrorism') Nikolai Bucharin had concluded - after having formulated in his 'Communist Programme': 'the dictatorship of the Working Class means State Power for the Working Class, strangling the bourgeois and the landlords' and 'destroying the bourgeois state and the bourgeois power': 'Hence we see that it is necessary to infringe all liberties of the enemies of the Revolution. In the Revolution, there is no room for the enemies of the People and of the Revolution' (cf., also cit Bernstein [1923] 118 f; translation into English by A.B.).

${ }^{53}$ This disturbance has a double foundation: (i) in itself, given the totalitarian character of Soviet-Communism, but also (ii) against the background of Loewenstein's advocating capitalism (see supra fn 16).

${ }^{54}$ But also the Austrian Max Adler, although also (as Bernstein, see previous fn but one) contesting the bolshevist dictatorship of the Communist party (see Adler [1922] 188 f), wrote bluntly (ib, 201): 'Die Diktatur des Proletariats ist Gewalt einer Klasse gegen die andere, ... die fortgesetzt werden muß . . . bis zu ihrer Vernichtung, weil erst dann die klassenlose Gesellschaft möglich ist' ('the dictatorship of the proletariat is the application of force of one social class against the other,... which has to be continued until the other class is destroyed, because only then a classless society is possible' [!; translation by A.B.]). 


\section{THE 'UNSAID'55 GERMAN HISTORICAL BACKGROUND}

Loewenstein does not convey the impression of absolute originality - in contrast, the second part of his article starts with '[s] ome illustrations of Militant Democracy' (Finland, Estonia, Austria ${ }^{56}$ and Czechoslovakia). Most strikingly, however, Loewenstein does not say a word - except a very imprecise mention of the temporary prohibition of the armed forces of the NSDAP ${ }^{57}$ - about the German attempts to set the principle he favours in place - although it is more than likely that it was exactly his home country which - on the national level as well as, in particular, on the federated State level of Bavaria - inspired him to develop his concept $^{58}$ :

\subsection{The German national level}

2.1.1. The constitutional background and the antecedents. Article 48 (2) of the German Constitution of 11 August 1919 ('Weimar Constitution'; WC) ${ }^{59} \operatorname{ran}^{60}$ :

'Der Reichspräsident kann, wenn im Deutschen Reiche die öffentliche Sicherheit und Ordnung erheblich gestört oder gefährdet wird, die zur Wiederherstellung der öffentlichen Sicherheit und Ordnung nötigen Maßnahmen treffen, erforderlichenfalls mit Hilfe der bewaffneten Macht

\footnotetext{
${ }^{55}$ See supra fn 23.

${ }^{56}$ See in more detail infra section 3.

${ }^{57}$ See Loewenstein (1937) 427, where he regrets that only 'for less than two months, in spring 1932, the wearing of political uniforms in public' had been 'unlawful' (and even then not effectively enforced). See for the legislation at issue in more detail infra subsection 2.1.2.

${ }^{58}$ It is obvious that Loewenstein, not only born and living in Munich, the capital of Bavaria, but also a reader in Constitutional Law at the University there must have gained intimate knowledge not only of the process on the national, but, in particular, on the federated state level.

${ }^{59}$ The predecessor of this provision had been Article 68 of the previous constitution (of 16 April 1871; see Raithel/ Strenge [2000] 419 f; Poetzsch-Heffter [1928] 233; Anschütz [1933] 276) enabling the emperor to declare war in every part of the national territory (except Bavaria) in order to overcome threats to (internal) public security. We see here an unobtrusive normative source for Loewenstein's as well as C. Schmitt's dichotomy (cf. supra text by fn $49 \mathrm{f})$.

${ }^{60}$ The National President may, in case public order and security is to a large extent disturbed or in danger in Germany, take the measures necessary to restore public order and security, if necessary also making use of the armed forces. For this purpose he may, in their entirety or in parts, suspend the fundamental rights enshrined in Articles 114, 115, 117, $118,123,124,153$.' (unofficial translation by A.B.).
} 
einschreiten. Zu diesem Zwecke darf er vorübergehend die in den Artikeln $114^{61}, 115^{62}, 117^{63}, 118^{64}$, $123^{65}, 124^{66}$ und $153^{67}$ festgesetzten Grundrechte ${ }^{68}$ ganz oder zum Teil außer Kraft setzen.'

Although implementing of legislation, as required in section 5 of this Article, was never adopted $^{69}$, this provision had been quite frequently used, in particular during the first years of the Republic of Weimar, by the National President of the time, Friedrich Ebert, a Social Democrat, at that time mainly directed against Communists ${ }^{70}$, and again following the spring of 1930, after the end of the last national government based on a majority in the National Parliament $^{71}$, by the National President Paul v. Hindenburg, as an alternative method to ordinary legislation ${ }^{72}$, to secure the efficiency of the national government headed at the time by Heinrich Brüning. ${ }^{73}$ At that time, the background for the use of authoritarian rule, therefore, was not yet so much the necessity of defence against rising totalitarianism ${ }^{74}$, but simply the lack of coherence and willingness to cooperate among the parties of the traditional 'Weimar coalition', i.e. Liberals, the Catholic Party and the Social Democrats. ${ }^{75}$ It may be that exactly this fact had already exhausted this option before it could have served its genuine purpose.

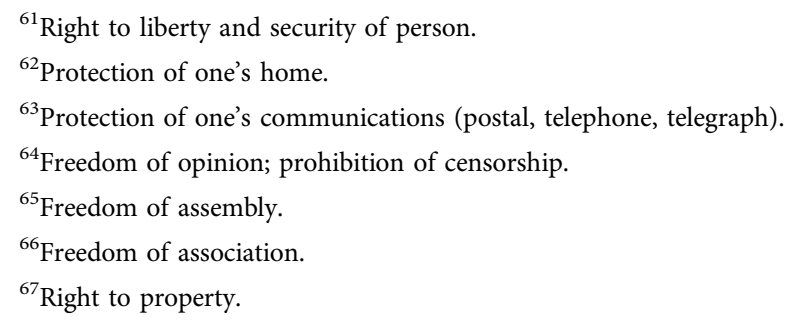

${ }^{68}$ This list did not include Articles 22 f, governing the election of the National Parliament, in particular requiring, in Article 25 (2), elections to be held 60 days after dissolution by the National President, nor Article 125, granting the fundamental right to vote. Hence, contemporary doctrine was of the opinion that general elections could not legally be suspended under Article 48 (2) WC (cf. Poetzsch-Heffter [1928] 240; Anschütz [1933] 289; even Carl Schmitt, although advocating for a larger interpretation of Article 48 (2) WC, had in this respect produced -still in 1928 - the same result, cf. [1928a] 246). This limitation would acquire decisive importance, at least in hampering Schleicher's proposal in January 1933 (see infra fn 106).

${ }^{69}$ See Poetzsch-Heffter [1928] 246 f; Anschütz [1933] 281; Bracher (1964) 55, fn 98, 304 f; Raithel/Strenge [2000) 425.

${ }^{70}$ See Raithel/Strenge (2000) 423; cf. also Anschütz (1933) 279, and Bracher (1964) 52 f, in particular fn 94.

${ }^{71}$ See, for the reasons of the resignation of chancellor (= head of national government) Hermann Müller, Bracher (1964) $287 \mathrm{f}$, in particular $296 \mathrm{f}$.

${ }^{72} \mathrm{cf}$. Bracher (1964) $306 \mathrm{f}$. The first ordinance of this type was issued on 16 July 1930 (see Bracher, ib, 339, fn 27).

${ }^{73}$ Brüning, (as Carl Schmitt and Franz v. Papen) a conservative Catholic Westphalian (see Bracher [1964] $307 \mathrm{f}, 342 \mathrm{f}$ ) was appointed as chancellor on 30 March 1930 and dismissed on 30 May 1932. He was the first chancellor in the Weimar Republic to be more dependent on the goodwill of the National President than on the support of the parliamentary groups (see in more detail Bracher, ib, $322 \mathrm{f}, 339 \mathrm{f}, 416 \mathrm{f}, 426 \mathrm{f}, 511 \mathrm{f}$ ).

${ }^{74}$ When Brüning was appointed, the National Parliament was still composed in conformity with the elections of 20 May 1928 where the Communist Party got $10.6 \%$ and the NS only $2.6 \%$ of the vote. Although these figures changed considerably in the elections of 14 September 1930 where the NS increased their share to $18.3 \%$ and the Communists to $13.1 \%$ (cf. Bracher (1964) 364 f), it was only the elections of 31 July 1932 in which the NS (37.3\%) and Communists (14.3\%) together got a negative totalitarian majority of votes as well as of seats $(230+89$ out of 608$)$ the latter of which was maintained in the elections of 6 November $1932(196+100$ out of 585).

${ }^{75}$ See Bracher (1964) 292 f, 297 f, 301 f. 


\subsubsection{The Presidential Ordinances of 28 March 1931, of 17 July 1931, of 13 April 1932 and of}

14 June 1932. Specifically directed against the extremist action of Communists, but also, and in particular, of the NS and their right-wing partners on 28 March 1931 the National President issued an ordinance based on Article 48 (2) $\mathrm{WC}^{76}$ which brought tougher surveillance regarding political assemblies (in particular paragraph 1), including their advertising (by leaflets as well as by media) and which also enabled authorities to prohibit party uniforms (paragraph 8).

On 17 July 1931, a second ordinance (RGBl I, p. 371) obliged all periodic media to publish, on request, official announcements; moreover, paragraph 2 allowed the seizure of all issues which endangered public order and security. Several ordinances followed ${ }^{77}$, until on 13 April 1932, the direction taken by paragraph 8 of the first ordinance of 28 March was intensified by another ordinance which - based on intelligence from the Prussian Police ${ }^{78}$ - dissolved with immediate effect 'all military organisations' only of the NS-Party, in particular the SA and the SS. Finally, all these ordinances, together with the ordinance of 3 May 1932 (RGBl I p. 185) were codified by the Ordinance of 14 June 1932 (RGBl I, p. 297). Its public impression, however, was reduced to the fact that not only had the unconditional and specific prohibition only of NS armed forces imposed by the ordinance of 13 April 1932 not been maintained $^{79}$, but also paragraph 8 of the Ordinance of 28 March 1931 was replaced by an provision enabling only the national minister of the Interior to prohibit assemblies [paragraph $4(1)(2)]$.

That this (perhaps naive) attempt to once again pay tribute to the ideas of general law as well as of equal treatment in all parts of the national territory (both forming part of the rule of law) did, however, not imply a fundamental change of attitude of assessment of the NS - at least not by Franz v. Papen, appointed as head of government on 1 June 1932 - is evident from what happened during his term of office ${ }^{80}$ :

2.1.3. The draft of 24 November 1932. In summer and autumn 1932 the national government headed by Papen, a Westphalian conservative Catholic who, however, had to leave the Catholic

\footnotetext{
${ }^{76}$ RGBl I, p. 79, see Bracher (1964) 396.

${ }^{77}$ cf. paragraph 20 (2) of the PO of 14 June 1932, Nos 3-5.

${ }^{78}$ See Bracher (1964) $481 \mathrm{f}$.

${ }^{79} \mathrm{cf}$., also for the background, Bracher (1964) $545 \mathrm{f}$, who, however, reports (on p 548, in particular fn 109) obviously erroneously an 'ordinance of 16 June, RGBl I, p. 302', having cancelled the prohibition of the SA; but neither the first Implementing Ordinance (of 17 June 1932, RGBl I, p 302) nor the second Implementing Ordinance (of 17 June 1932, RGBl I, p. 306) deal with this matter. In fact, this cancellation was effected by (i) the Presidential Ordinance of 28 June 1932, RGBl I, p 339, and (ii) the Implementing Ordinance of 28 June 1932, RGBl I, p $339 \mathrm{f}$ (see Bracher, ib, $551)$.

${ }^{80} \mathrm{cf}$. also the Presidential Ordinances (i) of 29 July 1932, RGBL I, p. 389, (ii) of 9 August 1932, RGBl I, p. 403 f, (iii) of 9 August 1932, RGBl I, p. 407, and the Implementing Ordinance of 9 August 1932, RGBl I, p. 404 (see also Bracher [1964] 618).
} 
Party ('Zentrum') on 2 June $^{81}$ had indeed worked out plans for the transition to a 'New State' ${ }^{82}$ a vague concept drawing mainly ${ }^{83}$ from, in essence, traditional Catholic elements of the time favouring professional representation ${ }^{84}$ instead of political parties, aristo- and meritocratic balances ${ }^{85}$ against egalitarian votes ${ }^{86}$, the mythos of the 'sacrum imperium' ${ }^{87}$, the rule of natural $\mathrm{law}^{88}$ and ultimate responsibility before $\mathrm{God}^{89}$, as promoted by the Austrian conservative Catholic Othmar Spann, in particular, ${ }^{90}$ - recommended as an alternative to modern democracy as well to modern Totalitarianism and directed against the rise of Hitler's party ${ }^{91}$, but at the

\footnotetext{
${ }^{81}$ See Bracher (1964) 535, fn 30.

${ }^{82}$ See e.g. Braatz (1975) 321, 325 f; Bracher (1964) 536 f, 542 f, 593 f, 611, 614; Bracher/Sauer/Schulz (1960) 38. Apparently, Papen imagined, even after 30 January 1933, that he was still on the road to his 'New State' - otherwise he would not have welcomed Hitler's promise that the elections (for a National Parliament) of 5 March would be the last ones to be held (see Jung [1995] 14).

${ }^{83}$ Of course, the general reception of this thinking also, and in particular, outside the Catholic minority was (against the background of an unsatisfactory level of party cooperation, see supra text before fn 75) facilitated by a general authoritarian mood, not least favoured by German industry as well as by Prussian landlords, but also by the National President Hindenburg and by parts of the national armed forces ('Reichswehr'), see Bracher (1964) $289 \mathrm{f}, 299 \mathrm{ff}, 343 \mathrm{f}$. In this vein, Brüning, a member of the Catholic party and head of the national government 1930-1932 (see supra fn 73) had, as early as 1931, explored the option of restoring the monarchy, although not in the form it had been until end of 1918, but resembling more the British model, and neither calling back Wilhelm II nor the Crown Prince Wilhelm (but rather one of his sons, see Bracher, ib, $444 \mathrm{ff})$. On the other hand, by no means did all members or even leaders of the Catholic party adhere to this traditional concept (neither in the moderate form represented by Brüning nor in the fully-fledged approach characteristic of Papen); in particular the hesitance of Bavarian prime minister Heinrich Held to call Prince Rupprecht to power [see infra subsection 2.3.2] was, apparently, due to Held's democratic grounding [see infra text by fn 121]; for the two wings within the Catholic party as well as for the gradual predominance of the conservative wing after 1928, see Bracher, ib, 297, fn 40).
}

${ }^{84} \mathrm{cf}$. Bracher (1964) 541 ('ständisch getragene Selbstverwaltung').

${ }^{85} \mathrm{cf}$. Bracher (1964) $541 \mathrm{f}$; Braatz (1975) 320, 326. The intention was to add a first chamber to the National Parliament composed of members appointed for life (but, apparently, not hereditary ones).

${ }^{86} \mathrm{cf}$. Bracher (1964) $540 \mathrm{f}$.

${ }^{87} \mathrm{cf}$. Bracher (1964) 541.

${ }^{88} \mathrm{cf}$. Bracher (1964) 620, mentioning Papen's reference to the 'conservative rule of law' comprising 'faith in eternal law norms' in his grand programmatic speech of 28 August 1932.

${ }^{89} \mathrm{cf}$. Bracher (1964) 544; Braatz (1975) 321.

${ }^{90}$ See Bracher (1964) 545, fn 90. Spann himself, however, who had, at that time, already changed sides and clandestinely joined the NS movement in Austria, was nevertheless in 1938 detained for four months in the NS concentration camp Dachau (and severely ill-treated there).

${ }^{91}$ This strategic opposition against the NS movement did not hinder the tactical attempt to 'embrace' the NS in order to wear them out in government and, at the same time, make best use of their support among the electorate. Papen applied this approach in early August 1932 (cf. Bracher/Sauer/Schulz [1960] 40) and again when co-forming the government appointed on 30 January 1933 where he served only as vice-chancellor but thought, nevertheless that he could control Hitler (cf. Bracher [1964] 729, fn 211). 
same time also ${ }^{92}$ (and maybe even more so ${ }^{93}$ ) against the Communist Party. ${ }^{94}$ This goal was to be achieved not only by issuing Presidential Emergency Ordinances based on the said Article 48, but also by dissolution of the National Parliament and - this was a new emergency element not explicitly provided by the Constitution ${ }^{95}$ - by postponing elections for the new Parliament for an indefinite period. ${ }^{96}$

${ }^{92}$ Likewise, the coup d'état (likewise based on Article 48 (2) of the Weimar Constitution) against the Prussian caretaker government led by a Social Democrat (for the composition see infra fn 108) on 20 July 1932 ('Preußenschlag'; see in more detail Möller [2001] $298 \mathrm{f}$, in particular the references given in fn 275; Braatz [1975] $312 \mathrm{f}, 327 \mathrm{f}, 331 \mathrm{f}$ ) was not so much directed against the Social Democrats as such, but

- on the one hand aimed to solve the lack of coordination between the National State and the federated state of Prussia due to the flagrant disproportion (Prussia, as one of 18 federated states, comprising alone about three fifths of the population/territory of the National State) - a problem hidden in the pre-1918 era by the double personal union not only on the level of head of State (the Prussian king being ex officio also the German emperor), but also on the level of head of government (the national chancellor almost always also serving as Prussian prime minister, even in the case of Georg Graf v. Hertling who was a Bavarian, not a Prussian subject [!]) - but which was present during the whole Weimar period (cf. Anschütz [1933] 141 f, 145; Braatz [1975] 320, 323, 326; even the Social Democrats had, as late as 1928 , considered solving this problem in the traditional form of a personal union: by proposing that Otto Braun, the Prussian prime minister, also be appointed head of the national government, see Bracher [1964] 288, fn 5)

- meant to strengthen Papen's position with regard to the NS, see Bracher/Sauer/Schulz (1960) 39; cf. also Bracher (1964) 590, 730, that Papen himself had claimed that the intention of this coup had been to prevent NS control of the Prussian police, something which was feared could happen in the near future if the Prussian government were to be taken over by an NS led coalition; although Bracher himself was rather sceptical as to the accuracy of this claim (cf. also [1964] 582), this view has been backed by others, cf. Gerhard Hoogers/Gohar Karapetian ([2018] 257 f, 271). In addition one might speculate that Papen's loyalty to Prussia as such, compared with the National State (the 'Reich'), could have indeed been limited, given the religious tensions during the $19^{\text {th }}$ century (in which two Catholic archbishops of Cologne, Clemens Baron Vischering and Paul Melchers, had been arrested by the Prussian government). From both perspectives, the effect on the Social Democrats of this action would have amounted just to a sort of 'collateral damage'.

${ }^{93}$ From the contemporary perspective, Communism backed by the Soviet Union could have seemed to be much more dangerous than Hitler's party which then controlled only the governments of some minor German federated states (Anhalt, Mecklenburg-Schwerin, Oldenburg, Thüringen). This had indeed also been the view of Alfred Hugenberg, leader of the nationalist party, Hitler's coalition partner in the national government appointed on 30 January 1933 (see Bracher [1964] 350).

${ }^{94}$ In Prussia, the famous clash between the NS and Communists in Altona on 17 July 1932 ('Altonaer Blutsonntag') provided the final argument for the 'Preußenschlag' (see previous fn but one), cf. Möller (2001) 301; and Papen justified this coup on the very day (20 July 1932) in his national broadcast speech in particular with reference to the Communist danger (see Bracher [1964] 589). The seriousness of this warning has to be assessed against the facts that since the elections of (i) the Prussian Parliament on 24 April 1932 (ii) the National Parliament of 31 July 1932, the NS and Communists together had the - negative - majority in the respective Parliaments (cf. already supra fn 74); consequently, it was no longer possible to form a government backed by a parliamentary majority without the participation of one of these two parties on a national and on a Prussian level, respectively.

${ }^{95}$ Not only was this suspension not mentioned in Article 48 WC (see supra fn 68) nor in any other Article of the Constitution. What is more, due to its republican character Germany then lacked the monarch's reserve power (see supra fn 26). Hence, when Papen referred, as a historical precedent, to the conflict between Prussian prime minister Otto v. Bismarck and the Second Chamber of the State Parliament in 1862-1866 (see Bracher [1964] 672), he did not only overlook the fact that Bismarck's action could, at least formally, be considered to have taken place against the background of an unclear legal situation (cf. Kluckert [2018] 366 f), but that even if the government had dared to introduce a clear breach of the monarchical constitution this breach would still have been covered by the monarch's sovereign power - a power not at the disposal of the National President Hindenburg.

${ }^{96} \mathrm{cf}$. Quaritsch (1989) $42 \mathrm{f}$, with references in fn 71. Bracher (1964) 672, reports that even the next step had already been envisaged, i. e. calling a new Constitutional Assembly or a Constitutional referendum, thus circumventing the Parliament - a very dubious piece of information: why should the majority in such a referendum/Assembly have differed from that in the ordinary Parliament? 
These plans had - at that point in time ${ }^{97}$ - been strongly supported inter alia by Carl Schmitt (then a conservative Catholic Westphalian ${ }^{98}$, too) who was also involved in the drafting ${ }^{99}$; nevertheless these plans were dropped at that time due to the scepticism expressed by members of the armed forces ('Reichswehr'), among those the minister for defence in Papen's government and successor of Papen as chancellor, general Kurt v. Schleicher, on 1 and 2 December. ${ }^{100}$ The irony was, however, that only some weeks later also Schleicher made - once again ${ }^{101}$ - the same proposal ${ }^{102}$, but this time the Catholic Party ${ }^{103}$ (and their former member Papen ${ }^{104}$ ) insisted on a (formal ${ }^{105}$ ) return to parliamentary majority government ${ }^{106}$ - a position which led directly to Hitler's appointment on 30 January 1933.

\subsection{The level of Prussia}

On federated State level the Prussian ${ }^{107}$ government ${ }^{108}$ issued - even before the national government -measures targeted against the NS and communists:

- Prohibition for members of the Prussian Civil Service of membership in, or sharing activities with, or support for the NS and Communists by the Government Ordinance of 3 July $1930^{109}$

${ }^{97}$ Given what he had published only some years before (see supra fn 68) Schmitt must here already have changed categories: from the 'commissarial dictatorship' provided by the application of Article 48 (2) WC to an unwritten law of emergency (cf. [1928a] $234 \mathrm{f}$ ).

${ }^{98} \mathrm{cf}$. Quaritsch (1989) $25 \mathrm{f}$.

${ }^{99} \mathrm{cf}$. Quaritsch (1989) $42 \mathrm{f}, 84$; Schmitt did, however, not communicate directly with Papen, but with the ministry of defence then led by general Kurt v. Schleicher, the former spiritus rector (see Bracher [1964] 518 f, $532 \mathrm{f}$ ) and immediate successor of Papen as head of the national government.

${ }^{100} \mathrm{cf}$. Bracher (1964) $672 \mathrm{f}$, Raithel/Strenge (2000) 427, both referring to the negative expertise of lieutenant-colonel Eugen Ott.

${ }^{101}$ See previous fn but one.

${ }^{102}$ See Bracher (1964) 710.

${ }^{103}$ See Bracher (1964) 711; cf. in particular for the position of the chairman of the Catholic Party, Prelate Ludwig Kaas (in sharp contrast to that favoured by Carl Schmitt), Quaritsch (1989) $45 \mathrm{f}$.

${ }^{104} \mathrm{cf}$. Bracher (1964) 716.

${ }^{105}$ How closely together the positions were, however, is illustrated by the report of a conversation between Kaas and the National President Hindenburg on 18 November 1932 where also Kaas strongly supported the idea of 'authoritarian government' as an alternative to parliamentary democracy (see https://de.wikipedia.org/wiki/Ludwig_Kaas, fn 9).

${ }^{106}$ What is more: already in December 1932, when Papen had first made the very same proposal (see supra text before fn 96) all actors concerned had been fully aware of the unconstitutionality (see supra fns 68, 95) of the plan (see Bracher [1964] 672); while at that time, however, Hindenburg would have supported Papen (see Bracher, ib, 673), in January the National President also insisted that the Constitution be respected.

${ }^{107}$ Prussia was then by far the most important federated state in Germany (see supra fn 92).

${ }^{108}$ The dominant figure was the Social Democrat Otto Braun, with two minor exceptions in 1921 and 1925 prime minister from March 1920 until the 'Preußenschlag' (see supra fn 92). The last Prussian government based on a parliamentary majority was a coalition of three Social Democrats, three Catholics and two liberals.

${ }^{109} \mathrm{cf}$. Bracher (1964) 360. In contrast, the national government (at this time Brüning) did not yet share this attitude. 
- Prohibition of wearing NS uniforms of 11 June 1930 (withdrawn on 1 April 1931, due to a court decision) $)^{110}$

In addition, the Prussian Parliament modified its rules of procedure regarding the necessary majority for the election of the government just before the elections of 24 April 1932, thus enabling the previous government to stay in office even without a parliamentary majority. ${ }^{111}$ Otherwise, most probably an NS prime minister would have been elected by the State Parliament already as early as in May $1932^{112}$ - and thus from that point in time on would have had the Prussian police ${ }^{113}$ at his disposal. ${ }^{114}$

\subsection{The level of Bavaria}

2.3.1. Wearing uniforms by members of political parties prohibited. Bavaria - federated home state of Loewenstein and for almost the whole period of the 'Republic of Weimar' governed by the regional Catholic Party (the 'Bayerische Volkspartei' - BVP) - had already in 1930 taken measures against rising National-Socialism, in particular had prohibited (as strongly advocated by Loewenstein! ${ }^{115}$ ) the wearing of uniforms by members of a political party.

This prohibition, after a while imitated by other federated states ${ }^{116}$ and also backed by paragraph 8 of the aforementioned National Presidential Ordinance of 28 March 1931, had, however, to be withdrawn when this Ordinance was abolished, as already mentioned, by the Presidential Ordinance of 14 June 1932. A subsequent attempt of Bavaria's government which had issued, on the basis of Paragraph 64 of the Bavarian constitution then in force ${ }^{117}$ (the federated state counterpart to Article 48 of the national Constitution) a State Emergency Ordinance, to restore the essence of this prohibition was, however, finally blocked by a National Presidential Ordinance of 28 June $1932 .{ }^{118}$

${ }^{110}$ See Mennen (2013) 273. One consequence of this prohibition was that on 13 October 1930 the members of the newly elected (on 14 September 1930) National Parliament belonging to the NS group had to put on their uniforms within the Parliament building (see Bracher [1964] 376).

${ }^{111}$ See Bracher (1964) 502 f; Möller (2001) 299 f.

${ }^{112}$ In the elections of 24 April 1932, the NSDAP increased its share of the vote from $1.8 \%$ (1928) to $36.3 \%$, whereas the Social Democrats' share fell from $29 \%$ (1928) to $21 \%$. This relative majority would, according to the former rules, have sufficed to bring a new prime minister into office.

${ }^{113}$ As mentioned supra in fn 92, securing control over the Prussian police (their manpower then was almost equivalent to that of the national army!) motivated Papen to his 'Preußenschlag'.

${ }^{114}$ Pursuant to Article 45 of the Prussian constitution of 30 November 1920 then in force, all ministers were appointed by the prime minister.

${ }^{115}$ See supra fn 57 . Obviously Loewenstein only referred to the prohibition of the armed forces of the NSDAP on the national level, neglecting all the other initiatives on a national as well as, in particular, a Bavarian level.

${ }^{116}$ See, for Hessen and Baden, Mennen (2013) 273, for Prussia (where the prohibition was not a general one, but restricted to NS uniforms, supra subsection 2.2).

${ }^{117}$ Of 14 August 1919. The WC did not bar outright the use of these emergency powers enshrined in a federated state constitution, although on this basis any infringement of national law was considered to be illegal (see Anschütz [1933] 276).

${ }^{118} \mathrm{RGBl}$ I, p. 339. As already stated in the PO of 14 June 1932, prohibitions of this kind had to be issued in principle by the national minister of the interior (paragraph 2); competences of federated state authorities in that field were strictly limited to (i) cases of imminent danger, (ii) local application or (iii) individual cases and subject to control of the national minister (paragraph 1); see also https://www.historisches-lexikon-bayerns.de/Lexikon/Uniformverbot,_1930-1932. 
2.3.2. The idea of establishing Prince Rupprecht as a bulwark against NS. In late 1932/early $1933^{119}$ the idea of calling the former Bavarian Crown Prince Rupprecht to power (under Article 64 of the Bavarian Constitution then in force ${ }^{120}$ ) was discussed, calculating that the National President would not dare to overrule such an appointment. The attempt failed, however, not least due to the fact that prime minister Held was unwilling to become sufficiently subordinate to Prince Rupprecht. ${ }^{121}$

This idea as such was, however, not too far-fetched - there had been already a precedent ten years ago when the former prime minister Gustav Ritter v. Kahr had been appointed as 'Commissioner General' from 26 September 1923 until 17 February 1924 by the Bavarian government, pursuant to the afore-mentioned Paragraph 64, exercising dictatorial powers, including command of the national armed forces stationed in Bavaria. Although Kahr's appointment had then not been directed against Hitler, nevertheless this model would have provided much symbolic force because, during Hitler's attempt to start a coup d'état in Munich on 8/9 November 1923, it had been Kahr's decision not to join this action, but, on the contrary, to prohibit Hitler's party in the early morning of 9 November 1923 and to crush the so-called 'March to Berlin' while it was still in the centre of Munich (at the 'Feldherrenhalle' monument), which had been decisive for the failure of this first attempt by Hitler to seize power (and for his subsequent conviction). ${ }^{122}$

\subsection{The tragedy of the Presidential Ordinances of 4 and of 28 February 1933}

Against the background set out in subsections $2.1-2.3$ one can indeed gain the impression that Loewenstein's -at first sight general and purely theoretical - plea for a 'militant' reaction against 'fascism' is, in essence, not much more than a well disguised regret that the concrete attempts which had in fact been pondered or even set out on a national as well as on a federated state level had not been effective enough to stop Hitler's party in time.

This regret is the more understandable when taking into account that, immediately after having been appointed as head of national government, it was Hitler who was able to motivate the National President to issue exactly the type of ordinances Papen and Schleicher had requested before in vain ${ }^{123}$ : first, the one issued on 4 February $1933^{124}$ and second, after the fire in the National Parliament Building on 27 February, the Ordinance of 28 February $^{125}$ - and that it was

\footnotetext{
${ }^{119}$ There is evidence that prime minister Held threatened this option even in the afternoon of 28 February (in a telephone call with vice-chancellor Papen) trying to prevent paragraph 2 of the (then drafted) National President's Ordinance of 28 February 1933 (see infra lit D), see Raithel/Strenge (2000) 432, fn 102.

${ }^{120}$ Also Article 48 (4) WC would have provided a basis.

${ }^{121}$ See in more detail v. Aretin (1981) $513 \mathrm{f}$.

${ }^{122}$ Hitler did not forget this contribution - on 30 June 1934, in the context of the action against Ernst Röhm, Kahr was murdered in Dachau (see supra fn 47).

${ }^{123}$ Of course, the situations are different, but only in degree: it was not only Papen and Schleicher who had lacked a parliamentary majority; Hitler too, before the elections of 5 March 1933, did not enjoy a majority; his intention was, however, not to suspend general elections for an indefinite period - but in contrast, he aimed to win the elections - although with the support of this Ordinance which had intimidated already large parts of the electorate belonging to the opposition.

${ }^{124}$ RGBl I, p. 35, cf. Raithel/Strenge (2000) 428. This ordinance had already considerably hampered the opposition's activities in the campaign for the elections to the National Parliament of 5 March 1933.
}

${ }^{125}$ RGBl I, p. 83; cf. Raithel/Strenge (2000) 416 f, 428 f. 
exactly these Ordinances (the latter only allegedly directed, like most of its early predecessors ${ }^{126}$, only against Communist actions ${ }^{127}$ ) which now, administered by National Socialists, helped them into power - first on a national level (via the elections of 5 March $1933^{128}$ ), but very soon also on a federated state level ${ }^{129}$, in particular also in Bavaria ${ }^{130}$ - instead of barring them.

That also, and in particular, this latter Ordinance - 'for the protection of the People and the State' - was also directed against the Catholic party very soon became apparent when also in Bavaria from 9 March 1933 on, a national Commissioner took over the responsibilities of the state government (prime minister Held, consequently, finally resigning from office on 27 March). What is more, it was not only the Catholic Party which was forced to dissolve (as was every other party except the Social Democrats and the Communist Party which were prohibited), but also the Catholic students' associations were immediately brought under NS con$\operatorname{trol}^{131}$, thus severely hampering the further cohesion and expression of the academic elite $e^{132}$ of Catholic 'civil society'.

\section{THE AUSTRIAN CASE}

\subsection{The facts}

3.1.1. Chancellor Dollfu $\beta$ was perfectly aware of the German developments. First it has to be emphasized that, in particular, the head of the Austrian government ('Bundeskanzler') of that time, Engelbert Dollfuß, must have been fully aware of the situation in Germany, both on the national and the federated state level (in Prussia, but in particular in Bavaria) and within the Catholic milieu:

\footnotetext{
${ }^{126}$ See supra fn 70 .

${ }^{127}$ The first sentence of this Ordinance contains the motivation: 'zur Abwehr kommunistischer staatsgefahrdender Gewaltakte' ('to fend off Communist violence endangering the State'; translation by A.B.). This sentence obviously reflects the fact that it was the Communists who had been held responsible for the fire by the Government (this hypothesis was, however, never verified: indeed, several Communist leaders charged with that accusation were acquitted by the German Supreme Court ['Reichsgericht'] on 23 December 1933).

On the other hand, making the implicit cause explicit was a fairly new element (cf. Raithel/Strenge [2000] 435, refer-ring to only one predecessor, the emergency Ordinance of 3 May 1932, also directed against Communists which had been criticized in the media for breaching the principle of equal treatment; Raithel/Strenge themselves comment that singling out the ideological addressee could be understood as a restriction of application, but also that the State gave up its ideological neutrality, taking sides in the ideological warfare).

${ }^{128}$ See supra fn 19.

${ }^{129} \mathrm{cf}$. in particular the National Act of 31 March 1933, RGBl I p 153 ('Vorläufiges Gesetz zur Gleichschaltung der Länder mit dem Reich').

${ }^{130}$ See text right infra.

${ }^{131}$ See Fritz/Handl/Krause/Taus (1988) 48 f.

${ }^{132}$ Despite the term 'students' associations' these associations comprised, due to the principle of life-time membership, not only active students, but all former students who had finished their studies.
} 
- On the one hand, Dollfuß had not only met Franz v. Papen in 1931 at the Austrian Catholic Party's Congress in Klagenfurt ${ }^{133}$, but participated in September 1932 in the German National Catholic Congress in Essen where his invitation that the Congress should meet next year in Vienna 'was enthusiastically received'134, paying on that occasion a personal visit to the Bavarian prime minister Heinrich Held - who belonged to the very same social group as Dollfuß $^{135}$ - on 3 September 1932 at the Munich aerodrome. ${ }^{136}$

- On the other hand, Dollfuß, in his capacity as chairman of the alumni section ${ }^{137}$ of an Austrian Catholic students' association which at that time still belonged to the German umbrella association ('Cartellverband' - 'CV') was not only directly affected by the measures effected against this umbrella organisation and its member associations in Germany by National-Socialists as early as end of May $1933^{138}$, but was personally perceived by them as an 'enemy'. ${ }^{139}$ What is more, it was precisely these NS-measures which led to the declaration of independence of the Austrian (and Czechoslovakian) associations in early July $1933 .{ }^{140}$ From this point in time at the latest Dollfuß must have been aware that the German NS (government and party) also posed a severe threat to Austrian Catholics, the more so, because Hitler combined the positions of supreme head of the Austrian NS party with that of the head of the German national government ${ }^{141}$, without any reciprocal opportunity to interfere in Germany ${ }^{142}$ for the Austrian side. ${ }^{143}$

\footnotetext{
${ }^{133}$ See $v$. Schuschnigg (1938) 160.

${ }^{134}$ See v. Schuschnigg (1938) $160 \mathrm{f}$ (cit 163). Both Brüning and Papen had been invited to this congress, but both declined the invitation due to the personal tension between them, a fact which was very well noted by Schuschnigg (who had accompanied Dollfuß), speaking of 'a cold shadow' which 'could be sensed here and there' (cit ib, 162).

${ }^{135} \mathrm{Held}$ was also a member of several Catholic students' associations, one of them an Austrian one.

${ }^{136}$ https://austria-forum.org/af/Bilder_und_Videos/Historische_Bilder_IMAGNO/Dollfu\%C3\%9F\%2C_Engelbert/ 00623702. Dollfuß was accompanied here (I owe this knowledge to Karl Schrammel, secretary general of the Austrian Federation of Catholic Students' Associations [ÖCV]) by Otto Kemptner (on the left side behind Dollfuß), then Dollfuß' secretary in the Federal Chancellery and from 1. 8. 1933 on, secretary general of the Patriotic Front - a fact which underlines the political character of this visit.

${ }^{137}$ See right supra fn 132 .

${ }^{138}$ See right supra fn 131.

${ }^{139}$ See Fritz/Handl/Krause/Taus (1988) 9: Dollfuß and all other members of the Austrian government who were members of a CV association had been dismissed by the newly installed 'leader' of the CV, Edmund Forschbach.

${ }^{140}$ See Fritz/Handl/Krause/Taus (1988) $9 \mathrm{f}$.

${ }^{141}$ See Kindermann (1984) 34 f; Hanisch (1994) 317 (on a lower level the same model of a double role was applied: Theo Habicht, leader of the Austrian NS, was a member of the German national Parliament; see Hanisch, ib, 219); Wohnout (2014) 55.

${ }^{142}$ In principle, the Catholic Church could have played exactly this role, and indeed the Austrian bishops tried to step in (see infra fn 178), whereas their German colleagues had been duped by Hitler, cf., for background and motivation of the 'Declaration of Fulda' of 28 March 1933, Mikat (1962) 209 f, in particular 223 f, 235 (text).

${ }^{143}$ The situation at that time was similar to well-known situations where Communist parties in certain countries were backed and supported either by Soviet-Union or, after 1949, by the People's Republic of China.
} 
- Only in addition it should be mentioned that Dollfuß had, in 1920, spent several months in Berlin (the national capital as well as Prussian capital) as a student and met his wife there ${ }^{144}$; so it can be presumed that, from that time on, he had had much closer ties to Germany (and Prussia in particular) than the average Austrian politician of that time. ${ }^{145}$

This German prelude - and the fact that awareness of it was not shared among all Austrian actors to the same extent - is the main key ${ }^{146}$ to the proper understanding of the Austrian tragedy which followed:

\subsubsection{The Austrian developments}

3.1.2.1. The struggle to remain independent. Whereas already in April 1932 regional elections had resulted in a remarkable rise of the Austrian NSDAP, although not yet of German dimensions ${ }^{147}$, Dollfuß opposed and stressed at least from autumn 1932 on the capability of Austria to survive as an independent state ${ }^{148}$ - obviously a remarkable shift in the Austrian position which had been, from the very beginning of the Republic (originally named 'German Austria') that, after the decline of the Danube Monarchy, unification with the German National Republic was to be achieved as soon as possible ${ }^{149}$; this conviction of Dollfuß laid the basis for the struggle for independence following Hitler's appointment to head of the German national government. ${ }^{150}$ In contrast, Hitler was, after 5 March 1933, first of the opinion that Austria could be taken over in almost the same way as the German federated states. ${ }^{151} \mathrm{He}$ had, however,

\footnotetext{
${ }^{144}$ Alwine Glienke was born in Poppow (Lauenburg in Pommern) which meant that Prussia was her home State; cf. Schaunig (2010) 57 f; see also E. Weber (1935) 6.

${ }^{145}$ One exception was Ernst Rüdiger Prince Starhemberg, vice-chancellor since 17 May 1934 - but his impressions of Hitler (cf. Kindermann [1984] 111 ff) can only have supported Dollfuß' view.

${ }^{146}$ Hence, authors like Tálos (2013) who downplay the relevance of the 'resistance against NS' factor (cf. the quite cursory manner by which the phenomenon 'NS in Austria' is dealt with on pages $52 \mathrm{f}, 501 \mathrm{f}$ ) fail to grasp, despite many correctly reported individual facts, the very essence of the Austrian government of the time and, therefore, are led to $a$ fundamental misinterpretation of its aims and character.

${ }^{147}$ cf. Kindermann (1984) 61; Reisberg (1974) 148; Hanisch (1994) 147; see also Kreisky (1986/1995) 184.

${ }^{148}$ See Kindermann (1984) 62; cf. also Kreisky (1986/1995) 207 f, reporting there that he (Kreisky) was sent (by Benedikt Kautsky) already in 1929 when drafting his College thesis and in that context looking for support for his opinion that Austria was economically capable to survive, to Dollfuß, then still director of the Agricultural Chamber of Lower Austria.

${ }^{149} \mathrm{cf}$. the first sentence of Article 2 of the Act of 12 November 1918 on the form of State and Government, StGBl No 5; Kelsen/Froehlich/Merkl (1922) 66; Berchtold, (1998) 35 f, 82 f; Hanisch (1994) 265, 271, 308 f. Still in 1930, however, the League of Nations vetoed the attempt at a customs union (see Bracher (1964) 398 f; Kindermann (1984) 29; Berchtold, ib, $605 \mathrm{f}$ ). On the other hand already the fact that in 1929 when amending the constitution the position of the Federal President was shaped on the model of the German National President showed (not, however, without any controversy, see below fn 200) that Austria had increased her confidence in her existence as a independent state. Likewise, at this time the Austrian minister for Justice (later on chancellor) Schuschnigg no longer preferred to speak of 'unification', but of a mere 'alliance' (see v. Schuschnigg [1938] 167).

${ }^{150}$ This fact had already been explicitly and unconditionally stressed by Hanisch (1994) 317.

${ }^{151}$ cf. Wohnout (2014) $56 \mathrm{f}$.
} 
to learn that neither the takeover of the Pan-German party ${ }^{152}$ nor terrorist acts ${ }^{153}$ nor public demonstrations (like that of Bavarian minister for Justice Hans Frank in Vienna in May $1933^{154}$ ) nor economic pressure (the famous 1000 mark tax, a retorsion for the expulsion of Frank by the Austrian government ${ }^{155}$ ) would suffice ${ }^{156}$ :

On the contrary, being well aware of the full extent of the danger ${ }^{157}$ (in particular, that the NS did not need to wait for an absolute majority of votes ${ }^{158}$ in order to take over the country ${ }^{159}$ )

- already, immediately after the 5 March 1933, seizing the opportunity the events in Austrian Parliament of 4 March offered (see infra subsection 3.1.2.2), the decision was taken ${ }^{160}$ to prevent further general (and other ${ }^{161}$ ) elections ${ }^{162}$;

${ }^{152}$ cf. Berchtold (1998) 746: on 15 May 1933 this party formally subordinated to Hitler, but already on 16 April a preparatory manifesto was published (signed, on behalf of the Pan-Germans, by Straffner, former third president of the first chamber of Parliament [see infra fn 196]).

${ }^{153}$ cf. Wohnout (2014) 57, 63; Tálos (2013), 52 f.

${ }^{154} \mathrm{cf}$. Kindermann (1984) 63.

${ }^{155} \mathrm{cf}$. Kindermann (1984) 63; Wohnout (2014) 63.

${ }^{156} \mathrm{cf}$. for a consolidated view on the NS measures and the government's reactions also Hanisch (1994) $319 \mathrm{f}$.

${ }^{157}$ The victory of the NSDAP on 5 March in the German National Parliament elections immediately triggered not only more than 1000 assemblies in Austria (bonfires on the top of mountains not included) but a public demand by the Austrian NS leader as early as 6 March to hold general elections and to build a new, strong and 'national' government (see Berchtold [1998] 710). When discussing the measures of 7 March (see right infra in the main text) Dollfuß referred to precisely these events (see id, ib, 714).

${ }^{158}$ This finding makes a decisive difference to Loewenstein's second premise (see supra subsection 1.1.1; cf. also fn 22).

${ }^{159}$ As the former chancellor and minister of the army for many years Carl Vaugoin expressed it on 14 March 1933: a 30\% vote for the NS would suffice for their dictatorship (see Berchtold [1998] 727) - a quite accurate assessment, in particular because the NS would not have contented themselves with purely legal means, as can be inferred not only from the subsequent events preceding the insurrection of 25 July 1934 (see, for plans of action already to be implemented in 1933 but then vetoed by Hitler, Kindermann [1984] 150, and for the plan for various actions in several Austrian regions outside the capital actually implemented in July $1934 \mathrm{ib}, 159 \mathrm{f}$ ), but was then already wellknown from the German 'Boxheim' document (disclosed on 25 November 1931 to Frankfurt police authorities, see Bracher (1964) $431 \mathrm{f}$ ). Moreover, it had to be feared that riots provoked on the streets by the NS would give Germany a pretext for sending her army (such a scheme was in fact put into action in March 1938, Chancellor Schuschnigg referring to it in his Farewell Broadcast Speech of 11 March 1938 ('I declare before the world that the reports issued in Austria concerning disorders created by workers and the allegation that the situation had got out of control of the government were lies from A zo Z'; cit v. Schuschnigg [1938] Appendixes III, 328).

${ }^{160}$ See, in more detail, Wohnout (2014) $52 \mathrm{f}$.

${ }^{161}$ By ordinance of 10 May 1933 (BGBl Nr 172) local and regional elections were suspended, initially until 31 October 1933 (prolonged by ordinance of 12 October 1933, BGBl Nr 476, until 31 March 1934).

${ }^{162}$ Of course, it was the NS in particular who tried to enforce new general elections, in order to promote the unification of Austria with Germany (see right upra fn 157, but also Berchtold (1998) 746). This demand was still supported by the experience of the local elections in Innsbruck, capital of the Tyrol region, where - on 23 April 1933 the NSDAP's support rose from 3.82\% to 41.21\% (!; see Wohnout [2014], 59, fn 19; Berchtold, ib, 747). 
- already on 7 March 1933 surveillance of the press was enhanced ${ }^{163}$ and assemblies of every kind prohibited ${ }^{164}$;

- the efficacy of internal security was enhanced by

$\circ$ the centralization of the police ${ }^{165}$

○ the acceptance of assistance provided by the armed forces of patriotic associations ${ }^{166}$;

- in May 1933 (after the failure of negotiations with the $\mathrm{NS}^{167}$ ) NS uniforms were prohibited ${ }^{168}$, on 9 June the main medium of NS propaganda, the 'Völkische[r] Beobachter', as well as 13 other NS media $^{169}$, and on 19 June the whole NS party (SA and SS included) ${ }^{170}$ - but there was, in sharp contrast to Germany's behaviour with regard to 'enemies', no physical ill-treatment of NS individuals ${ }^{171}$;

- on 1 September, the ministry for the armed forces was relabelled 'ministry for defence of the country' ('Landesverteidigung') and in paragraph 2 of the Federal Act on Defence the purpose 'defence of the frontiers of the State' upgraded (from litera $c$ to litera a) ${ }^{172}$

- from 7 to 12 September 1933 the 'General German Catholic Congress' took place in Vienna ${ }^{173}$ and attracted several tens of thousands of participants, although not officially recognized by the German authorities and, hence, participation from Germany was impeded. In this context, the famous speech of Dollfuß at the Viennese Turf on 11 September ${ }^{174}$ marked the start of the

${ }^{163}$ See the ordinance based on the KWG BGBl 1933/41, obviously partly derogating the Decision of the Provisional National Assembly of 30 October 1918, StGBl No 3. On 26 April 1933, an ordinance directed against the dissemination of leaflets and other printed material the content of which could disturb public order, followed (BGBl No 155).

${ }^{164}$ Strictly speaking, the chancellor (then also competent in matters of internal security) did not in general prohibit assemblies by an ordinance but issued an instruction that the competent authorities should, without any exception, prohibit assemblies based on paragraph 6 of the Act on Assemblies (RGBl 1867/135; see Berchtold [1998] 715, 721, fn 52).

${ }^{165}$ By ordinance of 0.13 June 1933, BGBl No 226, regional commanders of the police ('Sicherheitsdirektoren') subordinated directly to the minister (then the chancellor himself) were established. Already by ordinance of 10 March 1933 , BGBl No 43, a federal police authority had been established in the capital of the Tyrol region, Innsbruck (for the reason for this choice see right supra, fn 162).

${ }^{166}$ See Kindermann (1984) 109; Staudinger (1971) 297 f, 360 f.

${ }^{167} \mathrm{cf}$. Berchtold (1998) $747 \mathrm{f}$.

${ }^{168}$ As a precondition thereof, Dollfuß had felt the need to prohibit (at least formally) the armed forces of the Social Democrats (see infra fn 285).

${ }^{169}$ See Kindermann (1984) 108.

${ }^{170}$ See Kindermann (1984) 109. Also here (cf. supra previous fn but one) this prohibition was preluded by the prohibition of the (small and unimportant) Communist Party on 26 May (see Wohnout [2014] 66).

${ }^{171}$ cf. Schölnberger (2010), 3: 'In Wöllersdorf wurde weder gehungert noch gefoltert noch gemordet.' cf. also Tálos (2013), $285 \mathrm{f}$, in particular $291 \mathrm{f}$, and $581 \mathrm{f}$.

${ }^{172}$ See BGBl 1933/392.

${ }^{173}$ According to the invitation made by Dollfuß in Essen 1932 (see supra text by fn 134); cf. also Schuschnigg (1938) $184 \mathrm{f}$.

${ }^{174}$ 'Trabrennplatzrede' (for the full text, see https://austria-forum.org/af/Wissenssammlungen/Symbole/Faschismus_-die_Symbole/Trabrennplatzrede_1933); cf. also v. Schuschnigg (1938) 184; Wohnout (2014) 67; Jabloner (2014) 103; Huemer (1975) $241 \mathrm{f}$. 
'new state ${ }^{175}$ - not least understood as the "better German State ${ }^{176}$, i.e. the civilized and Europe-oriented alternative to NS barbarism within the traditions of Catholic religion, German culture and population and, thus, introducing a new (and for Hitler in particular dangerous) level of (spiritual) quality ${ }^{177}$ into the resistance to NS pressure; ${ }^{178}$

- on 1 May 1934, a fully-fledged new constitution - offering rule of law ${ }^{179}$ as well as fora for Parliamentary deliberation, but avoiding general elections - was adopted (subsection 3.1.2.3)

- Not even the assassination of Dollfuß on 25 July 1934 in the course of an NS insurrection ${ }^{180}$ brought the NS immediate success - but from that point on resistance weakened remarkably.

3.1.2.2. The Self-Blockage of the Austrian Parliament on 4 March 1933. These substantive measures (just mentioned supra in subsection 3.1.2.1) as such were, however, not only facilitated, but in fact triggered by a contingent event $\left(\right.$ almost ${ }^{181}$ ) completely outside the NS context (3.1.2.2.1); nevertheless it was exactly the evaluation of this event which played - although the connection was, in a rational analysis, nothing but a bizarre mix-up - a decisive role in the evaluation of the substantive measures (3.1.2.2.2).

3.1.2.2.1. The self-blockage as such and options for a way out. On Saturday (!), 4 March 1933, in the course of a highly emotional plenary discussion and against the background of a very

${ }^{175}$ The speech started with the commitment: 'Wir wollen das neue Österreich' - the similarity to Papen's 'New State' (see supra fn 82) is evident.

${ }^{176} \mathrm{cf}$. Kustatscher (2016) $414 \mathrm{f}$, in particular the references in fn 1,168; see also v. Schuschnigg (1938) $6 \mathrm{f}, 185 \mathrm{f}$; E. Weber (1935) 63 f, 75 f, 206, 234 f; Zeyringer/Gollner (2012) 482; Zenker (2016), 19; Tálos (2013), 70, 74 f.

${ }^{177}$ The Austrian constitution still retains an allusion to this spiritual element of defence when defining the four dimensions of 'fully-fledged defence of the country' in Article 9a (2) B-VG since BGBl 1975/368 as military, spiritual, civic and economic.

${ }^{178}$ cf. for this dimension in more detail Kindermann (1984) $52 \mathrm{f}$. Also the Austrian Catholic Bishops had already issued in December 1933 a verdict against NS, in sharp contrast to their German counterparts who had cancelled their prior verdict quite soon after Hitler's rise to power on 28 March 1933 (see supra fn 142). Against the background of the traditional global unity of the Catholic Church this Austrian contradiction of the German declaration amounted to its formal withdrawal (also and in particular with regard to the German Reich!) already three years before the papal Encyclica 'Mit brennender Sorge' of 14 March 1937 was issued, thus underlining the official argument of the Dollfuß government that Austria was then (apart from Saarland and the city of Danzig) the only part of Germany which had kept her independence from NS and where, therefore, Catholic Church was still free to utter the truth (see also Kindermann, ib, 53). Against this evidence the assessment of Kreisky (1986/ 1995) 211, that there had hardly been any difference between Hitler and Dollfuß (and, thus, the latter's attitude of resistance was not credible) shows a remarkable rejection of the facts (cf. for such an attitude already supra fn 3 ).

${ }^{179}$ See infra fn 237.

${ }^{180}$ See in more detail for these events - which are the best ex-post-facto proof for the level of danger Austria had been facing since 5 March 1933 - Kindermann (1984) $139 \mathrm{f}$.

${ }^{181}$ The issue of the Parliamentary debate had been the application of an ordinance of 27 July 1914, RGBl No 155, sanctioning strikes in the public service, with regard to a strike of railway workers on 1 March 1933 (cf. also Tálos [2013] 31). This strike, however, had been instigated mainly by the NS, although Catholic and Social Democrat trade unions felt obliged to support this strike (see Berchtold [1998] 699). It may well be that this specific background contributed to the government's resoluteness during the debate. 
narrow government majority, suddenly all three presidents of the first chamber of the Austrian Parliament ('Nationalrat') resigned. ${ }^{182}$ Obviously, Dollfuß could not have planned this development (the first president, who initiated it, was Karl Renner, a very prominent Social Democrat, the third one, who gave full effect to it, a Pan-German). ${ }^{183}$

Apparently, not only the opposition ${ }^{184}$, but also the government ${ }^{185}$ (the Federal President included $^{186}$ ) were still for a while - although without any in depth legal analysis! ${ }^{187}$ - of the opinion that there would be some legal way to solve the impasse, caused by what, at first sight, had been no more than a technical mishap and focused on the aspect of political will ${ }^{188}$. The

${ }^{182}$ There is no doubt that all three presidents in fact stepped down from their office as such, rather than just leaving the chair of the session temporarily, cf. Berchtold (1998) $704 \mathrm{ff}$ (emphasis added), in particular 704, also fn 10 (where with regard to the first president Karl Renner we read (i) 'Ich lege meine Stelle als Präsident nieder', and, even more precise: (ii) 'Er legte sofort das Amt zurück'), 706 (where the discussion of whether resignation from office had legally been possible is referred to), and 717, fn 42, first part (where Renner, in a statement of 9 March 1933, argues that a president even in statu demissionis still has obligations). For the answers of the government and of the Federal President (who both had the understanding that a full resignation had happened) see infra fn 197 and fn 199, respectively.

Resignation from this office was also - although not unanimously - considered as allowed and, thus, valid (cf., for the contemporary mainstream view of the doctrine Jabloner [2013] $377 \mathrm{f}$, (i) with regard to the office of the head of State 377, fn 2, $381 \mathrm{f}, 386 \mathrm{f}$, (ii) with regard to the office of the president of the National Assembly 388 . The opposite was advocated among academia by Ludwig Adamovich sen. (see Jabloner, ib, 377, fn 1, 380 f), and among practitioners by Karl Seitz, then mayor of Vienna (see Berchtold [1998], 706, who himself, however, forms part of the mainstream, too, see ib).

Hence it required formal legislation (insertion of a paragraph 38a in the Act on the Rules of procedures by KWGOrdinance of 24 April 1934, BGBl Nr 238) to reactivate the House (see infra fn 203).

${ }^{183}$ See in more detail, Janystin-Nowak (2014) $7 \mathrm{ff}$; Berchtold (1998) $699 \mathrm{ff}$. From a modern perspective it is really hard to understand how frivolously the parties concerned put at stake the constitution and the state - apart from the levity mentioned in the previous $\mathrm{fn}$ it has to be emphasized that the sole purpose of the resignations (to reactivate the right to participate in the parliamentary poll at issue of the respective president, by blocking the same right of the succeeding president) by no means required resignation from office, but only to temporarily leave the chair (the provision at issue, paragraph $60 \mathrm{~A}$ of the rules of procedure running: 'Der Vorsitzende stimmt ... niemals mit').

${ }^{184} \mathrm{cf}$., apart from the activities of former third president Straffner, in particular the resolutions of the second chamber of Parliament (the 'Bundesrat') on 17 March 1933 and of the Viennese regional assembly where the Social Democrats held an absolute majority on 9 March 1933, of the Salzburg regional assembly and of the regional assembly of Lower Austria where the Social Democrats together with the NS held the majority on 10 and 14 March, respectively (see Berchtold [1998] $738 \mathrm{f}, 721 \mathrm{f}, 724$ and 728, respectively).

${ }^{185}$ On 8 March 1933 the government declared that there was 'no State Crisis', because (i) Federal President and government were in office and (ii) the government did not wish that the country to be deprived permanently of Parliament (see Berchtold [1998] 716).

${ }^{186}$ President Wilhelm Miklas was still, on 20 March, of the opinion that the appropriate instrument to solve the impasse was an emergency ordinance issued by him; with regard to the necessary requirement for this, i.e. the consent of the permanent subcommittee of the main committee of the first chamber of Parliament, he consequently urged consent from 'the parties' (see Berchtold [1998] 741).

${ }^{187}$ It is really striking that, apparently, when this question arose it was not immediately treated as one needing solid legal expertise, neither by the legal service of any institution (with regard to the government's service we read only that its head, Hugo Jäckl, had, in the course of a meeting of the governmental groups on 14 March, been put a question to which he responded in an unwelcome way (see Berchtold [1998] 727) nor by academia.

${ }^{188}$ Paradigmatically, on 14 March Odo Neustädter-Stürmer (Marquess de Gozani, then representative of the Patriotic Guards, later secretary of State and minister) admitted in an internal discussion of the governmental groups that it was well-known that a solution could be found, however, before that certain political goals should be attained (see Berchtold [1998] 727). 
same view has been held up to the present, almost unanimously, by the community of Austrian lawyers ${ }^{189}$ and historians ${ }^{190}$ or political scientists. ${ }^{191}$ Most interestingly, however, Klaus Berchtold had already pointed out that in principle ${ }^{192}$ - as a more meticulous examination ${ }^{193}$ reveals - after having accepted that full resignation had taken place with regard to all three presidents - there was indeed no constitutional way ${ }^{194}$ at all left open to resolve the situation:

- With regard to the attempt by the former presidents, in particular of the third one, Sepp Straffner (who had stepped down last) simply to continue to act until new presidents were elected $^{195}$, the government had already on 9 March 1933 published a formally ${ }^{196}$ fully correct answer stating that there was no provision entitling a former president of the House who had voluntarily stepped down to continue to act. ${ }^{197}$ Also the Federal President, Wilhelm Miklas, was of the opinion that exactly that element of analogy which Straffner's interpretation of the Parliament's rules of procedure implied ${ }^{198}$ hindered its application ${ }^{199}$

${ }^{189} \mathrm{cf}$, parte pro toto, Wiederin (2014) $75 \mathrm{ff}, 75 \mathrm{f}$, who states, without any references or argument (thus indicating that he is staying on common ground) that the federal government abused the resignation of the three presidents to prevent further sessions of Parliament and to legislate by ordinances. cf. also that Manfried Welan had blamed Wilhelm Miklas, then head of State, for not having resigned (see Wohnout [2014] 60, fn 22), although in this case no successor could have taken office any more, because the National Assembly, presided over by the president of the 'Nationalrat', would have been needed (Article 62 (1) read in conjunction with Article 39 (1) B-VG). The observations of Brauneder $(2009,232)$ are also much too superficial and, in the end, incorrect (as will be demonstrated infra; cf. also Balthasar [2021], section III/A).

${ }^{190}$ See, also parte pro toto, Hanisch (1994) 304, stating both fatalistically and superficially: 'Wer die Spielregeln von Demokratie und Verfassung so grob verletzte, mußte in der Diktatur enden.'; Wohnout (2014) 60.

${ }^{191} \mathrm{cf}$. Tálos (2013), 5 f, who proposed two legal solutions:

(i) dissolution of the Nationalrat by the Federal President or

(ii) amendment of the rules of procedure by an Emergency Ordinance issued likewise by the Federal President Neither of which was viable without infringement of the letter of the Constitution, as demonstrated right infra.

${ }^{192}$ See Berchtold (1998) 705 f, 715.

${ }^{193}$ Only a few years before the publication of Berchtold's book, Spanner (1980, 42) was also still contenting himself with a purely superficial - and eventually incorrect - assessment (‘. . . weder der Bundespräsident noch die Bundesregierung entschlossen sich, den wohl möglichen Weg über eine ,Notverordnung' nach Art. 18 B-VG zu beschreiten'; emphasis added).

${ }^{194}$ To be more precise: there was no way which did not imply a breach of ordinary constitutional law (see, however, for the option of recurring directly to the fundamental order, infra fn 218).

${ }^{195}$ See Berchtold (1998) 717, fn 42 (first part) where we read that the former first president Renner still assumed responsibilities, and 719, $730 \mathrm{ff}$, for the attempt of former third president Straffner to convoke a plenary session of the House.

${ }^{196}$ Against the fact that it was precisely this former third president, Straffner, who would sign, only one month later, a collaboration agreement with the NS (see supra fn 152), it is perhaps not too far-fetched to presume that this specific background might have facilitated sticking to the formal argument.

${ }^{197}$ See Berchtold (1998) 717, fn 42 (second part; emphasis added): 'Es gibt derzeit kein Präsidium des Nationalrates, es gibt auch keinen Punkt in der Verfassung oder in der Geschäftsordnung, der einem ehemaligen Präsidenten des Nationarates, der freiwillig auf seine Stelle verzichtet hat, das Recht gibt, sich Pflichten oder Rechte eines Präsidenten des Nationalrates zuzusprechen oder sie auszuüben.'

${ }^{198}$ Straffner himself admitted this element (see Berchtold (1998) 714, fn 37), but, apparently, followed a different methodology.

${ }^{199}$ See Berchtold (1998) 729. 
- As to the option of issuing an Emergency Ordinance of the Federal President (Art 18 (3)-(5) B-VG), a provision inserted in the constitution only in 1929, shaped after the model of Article 48 of the Weimar Constitution, but mitigated in several regards ${ }^{200}$ due to the Social Democrats' opposition ${ }^{201}$ ), more than one condition for its applicability was not met. $^{202}$

${ }^{200} \mathrm{cf}$. Berchtold (1998) $532 \mathrm{f}, 564,572$. In particular the requirements - none of them already part of the Government's Draft Bill (Article I $₫ 9$ RV 382 Blg NR III. GP, 3) - that

- the issuing of the ordinance was restricted to times where Parliament was not assembled and

- needed the consent of a parliamentary committee resembled Article 55 of the Prussian Constitution of 30 November 1920. Given the close contacts between the Austrian Social Democrats and the German Social Democrats (in particular Otto Bauer - former Austrian secretary of State for foreign affairs and in particular enthusiastic about unification with Germany, see Hanisch [1994] 139, 265, 271 - was highly respected and influential among left wing members of the SPD, cf. Zarusky [1992], $276 \mathrm{f}$; Wollenberg [2003]) it is very likely that in this regard the Prussian Constitution (of 30 November 1920) served as a model for the opposition, as did Article 48 (2) WC for the government's side. What the Austrian Social Democrats, however, overlooked was the difference in status: Prussia, as a federated State of Germany, could more easily do without a fully-fledged emergency instrument than could Austria as a sovereign State. Moreover, while Article 48 WC was also applicable - and even on two levels! - to meet dangers arising in Prussia (whereas Article 48 (2) WC was a tool of the National President, Article 48 (4) WC granted the same competences to the government of the federated state, thus overruling any limitations enshrined in the federated constitution) a comparable safeguard was completely lacking in Austria.

As pointed out in the next fn but one, it was precisely these additional limitations which made the Austrian instrument unfit to solve the crisis of 4 March 1933.

${ }^{201}$ Even after 4 March 1933, Otto Bauer, then leader of the Social Democrats, firmly opposed any enlargement of this provision, fearing it could serve as a basis for fascism (cf. Berchtold [1998] 735, fn 84) - thus completely negating (cf supra fn 3) the fact that also legitimate regimes could fail without some back-up system (so that, therefore, the proper attitude is not to avoid effective emergency powers outright, but to construe them in a way compatible with the purposes of a legitimate state).

${ }^{202}$ The most pertinent problem was that such an ordinance needed the consent of a parliamentary sub-committee which had not yet been elected (the so-called 'Ständige[r] Unterausschuss des Hauptausschusses des Nationalrates'). During the first days following 4 March 1933 there had indeed been attempts to rectify this omission (cf. also supra fn 186) which was, as such, still perfectly possible because this committee, although in fact chaired by president Renner, had had, legally speaking, its own 'chairman' (see paragraph 13 (6) of the Act on Procedures, BGBl 1920/10) and Renner had not stepped down in this capacity, too) - but they failed due to disagreement among the parties (see Berchtold, 1998] $741 \mathrm{f}$ ). However, despite these attempts, the constitution of this committee (as the necessary precondition for its operability) would have failed at any rate, because paragraph $23 \mathrm{~A}$ of the rules of procedure had conferred this task on the president of the House (a position which had been, as previously mentioned, vacant since 4 March 1933). It was only in 1975 that paragraph 35 (3) of the Rules of Procedures Act (BGBl Nr 410) clarified that the constitution of an ordinary preparatory subcommittee is up to the chairman of the committee (but still it is not clear whether this provision does indeed apply to the extraordinary 'Ständige[r] Unterausschuss des Hauptausschusses des Nationalrates', too).

The second problem was that the rules of procedure could have been considered 'constitutional law' which could not be amended by such an ordinance (cf. VfGH 16 March 2001, G 150/00, VfSlg 16.151), and the third problem was that Presidential Ordinances based on Article 18 (3) of the Constitution required legislation in times when Parliament 'was not assembled', the peculiarity of the case at issue, however, being that the plenary was in fact 'assembled', but unable to act (hence, the session of 4 March 1933 was eventually closed only on 30 April 1934, on the basis of a KWGOrdinance [see next fn; see, for the latter two legal obstacles, already Berchtold [1998] 707, 715). 
- Although eventually, in April 1934, indeed used to convoke again the plenary ${ }^{203}$, an ordinance based on the $K W G^{204}$ was likewise inappropriate, because the KWG allowed legislative measures to be taken by the government only insofar as it was necessary to overcome shortcomings caused by World War I, not to solve an impasse created fifteen years later.

- Finally, not even the dissolution of the House by the Federal President, based on Article 29 (1) B-VG (a provision only recently, in 1929, inserted into the constitution), would have helped ${ }^{205}$, because the constitution of the newly elected House would have needed, pursuant to Article $2 \mathrm{~A}$ of the rules of procedure, to be chaired by 'the president of the former' House - and again meeting this requirement was impossible when, as in the situation at issue, all three presidents had resigned. ${ }^{206}$

3.1.2.2.2. The evaluation. Dollfuß and his colleagues in the Austrian Catholic party realized immediately - in contrast to the Social Democrats ${ }^{207}$ - the opportunity this event provided with regard to meeting the danger ${ }^{208}$ emanating from Hitler after his victory in the German National Parliament elections of 5 March $1933^{209}$, i.e.

${ }^{203}$ Ordinance of 24 April 1934, BGBl Nr 238.

${ }^{204}$ See supra fn 2.

${ }^{205}$ Moreover, it is far from obvious that the issuing of such a presidential ordinance would still have been allowed in this specific case where Parliament had already dissolved itself (see BGBl 1932/136), without determining a date for the elections so that, pursuant to Article 29 (3) B-VG, the dissolved Parliament could continue to act. According to both Raschauer (2003, point 14), and Konrath (2017, point 18), however, dissolution of Parliament by the Federal President requires that Parliament is still 'legally existent' - hence the opinion of Konrath (ib, point 42) that due to the fact that a Parliament already dissolved under Article 29 [2] B-VG continues to exist as an acting body, why it might still be dissolved under Article 29 (1) B-VG may be questioned; in fact, Lienbacher (2000, point 13) too emphasizes that a dissolution under Article 29 (2] B-VG is, legally speaking, already a dissolutio perfecta.

${ }^{206}$ Correspondingly, paragraph $5 \mathrm{C}$ of these rules stated that the period of office lasted for the whole period of the House and paragraph 6 that the presidents as well as the main committee remained in office until their successors had been elected by the new House. This whole set of provisions, however, did not take into account voluntary resignation nor the fact that the dissolution by the Federal President, inserted in 1929 on the constitutional level, implied the loss of office for all members of the House, only excepting the members of the permanent subcommittee of the main committee. So, from a strictly legal perspective, paragraph 6 of the rules of procedure had been unconstitutional since 1929 (nevertheless, it had not yet been annulled by the Constitutional Court and could, therefore, still be applied in 1930, after presidential dissolution of the House). Had Parliament, however, adjusted its rule of procedures to the amendments of the constitution in time (even the insertion of paragraph 21a, taking into account the permanent subcommittee of the main committee at all, was delayed until 30 November 1932 [!] which was the reason why it was not yet elected in March 1933 [see supra fn 202]) it would, most probably, have realized the need to take care of the case of the involuntary loss of office of the presidents of the House by presidential dissolution (and, in this way, also have solved the situation which arose in March 1933 and which turned out, without such an amendment, to be insoluble).

${ }^{207} \mathrm{cf}$. Wohnout (2014) $60 \mathrm{f}$ (Otto Bauer later on admitted that he had not sufficiently taken into account Hitler's victory in Germany when assessing the Austrian situation after 4 March 1933).

${ }^{208}$ In this respect Dollfuß indeed fell short of Loewenstein's device, because Dollfu $\beta$ needed this contingent opportunity to prepare his mind for the subsequent 'militant' actions; or, to put it differently: it remains a most interesting question what Dollfuß would have done if he had not been provided with this opportunity - by Providence, as Richard Schmitz, later mayor of Vienna, put it (cf. Hanisch [1994] 303, fn 56; Tálos [2013], 32; cf. also E. Weber [1935] 66, for the opinion of Dollfuß himself) - precisely at the time when the objective necessity arose.

${ }^{209}$ For the particular relevance of this date for the Austrian government see Wohnout (2014) $54,58 \mathrm{f}$. 
- to avoid in particular elections (at all levels) ${ }^{210}$ which would offer Hitler a pseudo-legal opportunity to repeat the takeover he had just performed in Germany

- to amend (somehow ${ }^{211}$ ) the Constitution (at least in the direction already intended in 1929 by the government ${ }^{212}$, which, however, had then not been approved by the Social Democrats required for the qualified majority ${ }^{213}$ ) -

although they were convinced ${ }^{214}$ that this intention would amount to a breach of the current Constitution; they relied, however, for justification of such a breach of the law on Catholic morality. $^{215}$

In such a situation one might really wonder what advice would have been given by the Constitutional Court:

Would - could - it really have contented itself with stating the obvious without offering any practical solution ${ }^{216}$ - the latter, however, necessarily implying some deviation from the letter of the Constitution?!

Moreover, had the Constitutional Court once accepted that a breach of the letter of the constitution was simply unavoidable in order to make the constitution work again with regard to the functioning of Parliament ${ }^{217}$ - could this first metapositivist finding with regard to rules of procedure not have paved the way for the more substantive insight that also - or, more precisely, with even much more legitimacy - the NS threat as such justified the suspension of some provisions of the Constitution to some extent, in particular the suspension of general

\footnotetext{
${ }^{210}$ See supra fns $161 \mathrm{f}$.

${ }^{211}$ As already stated supra (see text by fns $184 \mathrm{f}$ ), among all actors the impression prevailed that some legal way out of the impasse would always be possible if only the relevant parties would agree - a highly misleading illusion which only eventually was replaced by the insight that a veritable cutting of the Gordian knot would be necessary.

${ }^{212}$ Hanisch (1994), 304; Jabloner (2014) 103.

${ }^{213}$ Jabloner (2014) 102; Berchtold (1998) 735.

${ }^{214}$ What we see here is, therefore, the finding that the Dollfuß' government was convinced to do - in substance - the right thing although they were of the opinion that these actions implied the breach of law. Put in this way this attitude is an outstanding example of what Max Weber had, only some years before, named 'Verantwortungsethik' (i.e. 'ethic of responsibility', in contrast to 'Gesinnungsethik' (i.e. 'ethic of abiding to rules'), see [1919] 56; cf. also ib, 55 [italic emphasis original] ' . . . so gilt für den Politiker umgekehrt der Satz: Du sollst dem Übel gewaltsam widerstehen - sonst bist du für seine Überhandnahme verantwortlich').

${ }^{215}$ See Wohnout (2014) 54 .

${ }^{216}$ Apparently that was, however, exactly what the government feared (see Berchtold [1998] $750 \mathrm{f}$ ).

${ }^{217}$ In this regard the most convincing solution would have been to apply Art 18 (3) B-VG even without involving the inexistent permanent subcommittee (referring here to 'factual impossibility', i.e. the general principle of 'ultra posse nemo tenetur'). Given, however, that even then the Federal President would only have called back a Parliament of doubtful legitimacy (because it had, already eight month ago, dissolved itself; see right supra fn 205) and that electing a new Parliament was, with regard to the NS, an almost suicidal option, it is understandable that the government aimed to negotiate a 'full package' before any action was started (for the concrete action see infra fn 231).
} 
elections, thus elaborating a lawful alternative ${ }^{218}$ to the far too simple formulae of Louis de StJust $^{219}$, Carl Schmitt's dichotomy ${ }^{220}$, Nikolai Bucharin ${ }^{221}$ and, finally, Karl Loewenstein ${ }^{222}$ (and Karl Popper $\left.{ }^{223}\right)$ ?

Most unfortunately, however, history worked exactly the other way round: The government having more confidence in Catholic morality than in the interpretation of secular public law ${ }^{224}$ began to paralyze the Constitutional Court in a most sophisticated, but, of course, most incorrect way. ${ }^{225}$ In my opinion it is mainly this apparent (though, most probably, erroneous!) admission of guilt which has hindered, up to now, any serious legal discussion as to whether the substantive measures of the Dollfuß government directed against NS attempts at a takeover should- as is submitted here ${ }^{226}$ - be considered justified. ${ }^{227}$

${ }^{218}$ Although a thorough analysis of the most fundamental layer of the Constitution (the 'fundamental order') would have shown that there is indeed a hierarchy among the fundamental principles where self-preservation of the State (forming part of the republican principle) ranks on the very top (see Balthasar, Grundordnung, 471), whereas the ambit of the democratic principle is restricted to the sphere left open after compliance with all other principles, in particular also with the principle of the rule of law (see id, ib, 688), such a thorough analysis - even the awareness that the 'rule of law' formed at all part of this 'fundamental order' - was not yet at the disposal of the doctrine of the time (see Wiederin [2014] 92; cf. also, for the notion of the 'fundamental order' as such, which seems to be taken from the German Fundamental Act ['Grundgesetz'] 1949, Balthasar, ib, 19 f, fn 28). Moreover, there is, even today, no constitutional doctrine in Austria with regard to (the preconditions, operability and limits of) cases of emergency (cf. id, ib, 159 f; see already supra fn 1). cf. also Balthasar (2021), section IV/C.

${ }^{219}$ See supra text by fn 48 .

${ }^{220}$ See supra fn 49.

${ }^{221}$ See supra fn 52.

${ }^{222}$ See supra subsection 1.1 .

${ }^{223}$ See supra fn 48 .

${ }^{224}$ See supra fn 215; the reason for this bewildering finding seems to be what has already been pointed out supra in fn 1 , combined with what is stated infra in subsection 3.2.1.3: the mental gap between the secular, and in particular, lawyers' academia, and the line of thinking of the Catholic party.

${ }^{225}$ cf. Wiederin (2014) 76 ff; Berchtold (1998) 750 f; Stephan Hinghofer-Szalkay (2018) 357 f, 361 f. Nevertheless, even there the position of the government was not without any fundamentum in re: as a member of the Constitutional Court, Adolf Wanschura, put it when giving reasons for his resignation on 18 May 1933 (cf. Berchtold [1998] 751 f), at least half of the members had been appointed on the basis of proposals of parliamentary groups. Could it really be expected that these members - from whom, apparently, only the minority belonged to the government's side - would ignore the position their political parties had taken in the highly political questions at issue?

What we see here is the 'dark side' of national constitutional courts which need, with regard to their normal business, more political legitimation than ordinary courts, but might precisely because of this closeness be disqualified from rendering impartial judgements in most sensitive cases. I wonder whether here perhaps, de constitutione ferenda, the inclusion of elements of international arbitrage could help?.

${ }^{226}$ See infra subsections 3.2.2. and 3.2.3. From that point of view I cannot share the view taken only quite recently by the Austrian legislator when adopting the Act on Repeal and Rehabilitation, BGBl I 2012/8, in which the historical background of emergency measures has been completely ignored.

${ }^{227}$ In this case there is an even greater tragedy in the assessment found supra in $\mathrm{fn} 214$, because

- while the conviction to do the right thing was, then, correct, the conviction to have therefore to breach the constitution was incorrect insofar, as law itself (cf. right supra fn 218 ) provided a justification, thereby annulling the verdict of a 'breach'

- hence, the second, real breach of the constitution by blocking the Constitutional Court (meant to conceal the first 'breach') was simply unnecessary. 
3.1.2.3. The Constitution of 1 May 1934. At any rate on 30 April 1934 a new constitution was adopted $^{228}$ - with Parliament's consent ${ }^{229}$ to the government's ordinance based on the $\mathrm{KWG}^{230}$ and, thus, in formal compliance with (even over-fulfilment of) its paragraph $3^{231}$, but up to then unanimously contested as unconstitutional from the perspective of the BVG. ${ }^{232}$ Nevertheless this constitution - invoking in its preamble 'Almighty God' not only as the source of all Law, but also as the ultimate authority legitimizing the Austrian People's Act of Constituting this Constitution, thus apparently aiming at circumventing the problems of pure 'people's sovereignty' set out supra in subsection 1.2.2.3 - gained effectiveness in its own right ${ }^{233}$ - this being the decisive further step which the German

${ }^{228}$ This constitution was first published on 30 April 1934 (see Article II of the Constitutional Act BGBl 1934 I/255), but again promulgated on 1 May 1934 (BGBl 1934 II/1); it came into effect on 1 July 1934 (see Article III/paragraph 56 (2) of the Federal Act of 23 June 1934, BGBl 1934 II/75).

${ }^{229}$ Pursuant to paragraph 1 of the Act on the election of the national Parliament (House of Deputies), BGBl 1923/367, the House then consisted of 165 members. Article 44 (1) of the B-VG requiring the presence of at least the half of all members for the adoption of acts of constitutional rank, these two norms read in conjunction meant that a minimum of 83 members present was needed for constitutional amendments - a number not reached in the final sessions of 30 April 1934. However: KWG-ordinances (i) of 12 February 1934, BGBl I 78, amended by the ordinance of 16 February 1934, BGBl I 100, and (ii) of 27 February 1934, BGBl I 118, had annulled (i) all seats held by the Social Democrats as well as all claims of deputies on the electoral list (72) and, in addition, (ii) of all members who had left their party. According to the Official Protocol (cf. Parlamentsdirektion [2014] 129) the acting president of the session of 30 April 1934 had been of the opinion that for the purpose of this session the House was no longer made up of 165, but only of 91 members, 76 of whom had been present. cf. also Tálos (2013), $80 \mathrm{f}$.

${ }^{230} \mathrm{BGBl} 1934 \mathrm{I} / 239$.

${ }^{231}$ Whereas the second sentence of this paragraph only required the ordinances be submitted to Parliament (and to be cancelled if Parliament demanded; the submission was carried out on 30 April 1934 with all 417 ordinances based on the KWG, no demand was raised, see Parlamentsdirektion [2014], 124), government requested (albeit only with regard to the ordinance BGBl $1934 \mathrm{I} / 239$ ) for a formal approval of Parliament. Nevertheless, it is still one complex procedure (cf. Balthasar (2016) $130 \mathrm{f}$, do FN 616), not, as still Brauneder (2009), 234, apparently misunderstood it, two different methods of adoption.

In addition, Article 44 (2) of the B-VG requiring a referendum for the validity of fundamental changes in the Constitution was abolished by Article I of the Constitutional Act BGBl 1934 I/255 (according to current doctrine, this abolition would have required a referendum, see Balthasar [2006], $195 \mathrm{f}, \mathrm{fn} \mathrm{896,} \mathrm{but} \mathrm{the} \mathrm{doctrine} \mathrm{of} \mathrm{the} \mathrm{time}$ was less developed, cf. supra fn 218) and the Federal President Miklas confirmed, based on Article 67 (1) of the BVG, the formal constitutionality of the whole Act BGBl 1934 I/255. See also Balthasar (2021) fn 2.

${ }^{232} \mathrm{cf}$., parte pro toto, only Jabloner (2014) $105 \mathrm{f}$, fn 18, who is of the opinion that after the blockage of the CC (see supra text by fn 224) all further actions of the government based on the KWG were null and void, Brauneder (2009), $234 \mathrm{f}$, and Spanner, Entwicklung, 43 ('unter - rechtlich völlig unhaltbarer - Berufung auf das' KWG).

${ }^{233}$ cf. Böckenförde (1991) 105 f; cf. also Schupmann (2017) 134. 
government had not dared to make in $1932^{234}$ - and remained in force until March $1938 .^{235}$ It preserved (even emphasized) the essence ${ }^{236}$ of the rule of law $^{237}$ by denying any general suffrage. ${ }^{238}$

This constitution was, however, accompanied by Article III (2) of the Constitutional Act of 30 April 1934, BGBl I Nr 255, this provision (= the 'Enabling Act 1934') granting,

\footnotetext{
${ }^{234}$ See supra fns 100 and 106.

${ }^{235}$ On the basis that the 'reunification' of Austria with Germany on 13 March 1938 was 'null and void' (cit Moscow Declaration 1943; see also Article II of the Austrian 'Declaration of Independence' of 27 April 1945, StGBl No 1), the Constitution of 1 May 1934 remained, from a legal point of view, valid until it was replaced by the Provisional Constitution of 1 May 1945 (StGBl No 5).

${ }^{236}$ While Wiederin (2014) $83 \mathrm{f}$, despite his general assessment (see next fn) nevertheless realizes that there were some 'steps backwards' in the substance of fundamental rights from the standard of the B-VG (resp. the StGG, i.e. the former [and again current] fundamental rights catalogue) to the Constitution of 1934, these differences are, in my opinion, much more due to the greater realism (honesty) of the authors of the Constitution 1934 who refrained from proclaiming farfetched ideals which could not, at least not for the time being, be implemented in practice.

This finding may be illustrated by one provision, deserving particular attention in the context here at issue: pursuant to Article 16 (3) const cit all posts in the public service were no longer equally accessible (as stated in Article 3 of the StGG) for all citizens, but only for those citizens who were loyal to the State. While it is perfectly evident that also under Article 3 of the StGG and under much less dramatic circumstances than in $1934 \mathrm{f}$ no disloyal citizen could ever have enforced his/her appointment (mostly due to the fact that, according to the still current steady case-law of the CC, no citizen has any legal remedy to contest his/her non-appointment in court; see only Mayer/Muzak [2015] 622), the Constitution 1934 was naive enough to spell out this necessity - which, by the way, has also been paid tribute to in Germany since World War II, see
}

- German Federal Constitutional Court 22 May 1975, 2 BvL 13/73, BVerfGE 39, 334,

- and even, at least in principle, by the ECtHR 26 September 1995, ANo 17851/91, Vogt v. Germany, point 59, first sentence: 'The Court proceeds on the basis that a democratic State is entitled to require civil servants to be loyal to the constitutional principles on which it is founded', although paving the way, in the following sentences, for some reasonable mitigations.

${ }^{237} \mathrm{cf}$. for this assessment (not only from a contemporary, but also from a current perspective) Wiederin $(2014) 79 \mathrm{f}, 85 \mathrm{f}$, $91 \mathrm{f}$, who also emphasizes the structure of the constitution in which, unusually for that time, fundamental rights had been promoted to the top (ib, 82). In this regard we see here the aim to tie in again with the rule of law tradition given that the French Charte Constitutionelle of 4 June 1814, then the Constitution of the United Kingdom of the Netherlands of 24 August 1815 and, after the Revolution of 1830, also the Belgian Constitution of 7 February 1831 had already shown this structure. Likewise, only shortly after 1848, the Prussian Constitution of 31 January 1850 had also included a large catalogue of fundamental rights (Title 2, Articles 3-32) at the top. But also the (although much smaller) fundamental rights' catalogue of the Austrian Constitution of 4 March 1849 was ranked as Section III (after the sections dealing with the Realm and the Emperor, but before all those other sections regarding local communities and regions, Parliament and Government, Judiciary, Budget, Military ....).

${ }^{238}$ Although the Constitution of 1934 provided ample parliamentary machinery on federal, regional and local levels, the members of all these representative bodies had all been, in one way or the other, appointed. Hence, when assessing the character of the régime, Hanisch (1994) $310 \mathrm{f}$, prefers the labels 'authoritarian' or 'neo-absolute'. 
although until the full implementation of the provisions governing two of the advisory parliamentary bodies ${ }^{239}$, the federal government ${ }^{240}$, unlimited legislative powers, most fundamental amendments of the Constitution included. ${ }^{241}$

\subsection{The assessment}

\subsubsection{The differences between the Austrian situation after 5 March 1933 and the German situation in 1932}

\subsubsection{A Clearer and Stronger Position against NS in Austria.}

- Due to their 'Austro-Marxist' basis the Austrian Social-Democrats managed to maintain, to a far greater extent than in Germany, where the original movement split, at least for some years, into three parts (the Social Democrats, the Independent Socialists and the Communists), the unity of the 'working class movement ${ }^{\text {'22 }}$; consequently, not only did a Communist party belonging to the III. International Association (remotely-) controlled by Moscow play a much less important role in Austria than in Germany ${ }^{243}$, but the Social-Democrats as such - not controlled by Moscow or by any other foreign power either - did not pose a comparable threat, either. $^{244}$

- Whereas, from Papen's perspective, Hitler had been, in 1932, only the leader of a German political party supported by about one third of the electorate, but by no foreign power, the situation had, after the elections of 5 March 1933 at the latest, changed dramatically for Dollfuß: for him, Hitler was not only the leader of the Austrian NS movement (supported likewise by about one third of the Austrian electorate), but, in addition, the omnipotent head of government of a huge neighbouring country. ${ }^{245}$

${ }^{239}$ The Federal Councils for Culture and for Economy ('Bundeskulturrat' and 'Bundeswirtschaftsrat'), cf. Article III/ paragraph 56 (3) of the Federal Act of 23 June 1934, BGBl 1934 II/75; this delay in implementation was due to the fact that these Councils should be composed of delegates of the 'Professional Estates' (the core element of the Constitution 1934) the constitution of which (with the exception of only two 'Estates') had, however, not yet been achieved in March 1938, see Hanisch (1994) 316.

${ }^{240}$ In sharp contrast to the German Enabling Acts (of 24 March 1933 and of 30 January 1934, respectively; see supra fn 19), however, this governmental legislation needed, just like parliamentary legislation, the signature of the Federal President.

${ }^{241}$ Hence, this provision - then still in force, due to the delay mentioned in the previous fn but one - could be used to implement what then was pretended to be unification with Germany (cf. the Constitutional Act of 13 March 1938, BGBl No 75).

${ }^{242}$ cf., e.g., Kreisky (1986/1995) 144 ff, 152 f; Hanisch (1994) 127, 135 f; Leser (1988) 27; Reisberg (1974) 89 f.

${ }^{243}$ See even Reisberg (1974) 90.

${ }^{244}$ On the other hand, due to their limited ideology (see supra fn 3 ) cooperation between the Dollfuß government and the Social Democrats to jointly keep down the NS (as suggested, among others, later on by Kreisky [1986/1995] 210) was not an option either, cf. Kindermann (1984) $129 \mathrm{f}$, outlining what positions would then have to be accepted by the Social Democrats in the interest of an effective defence of the country.

${ }^{245}$ See supra text by fn 141 . 
Both elements taken together meant that for Dollfuß in 1933/34 the main danger obviously came from the $\mathrm{NS}^{246}$, not from the Communists (not to speak of the Social Democrats ${ }^{247}$ ).

3.2.1.2. The need for a safeguard for an indefinite period of time. Given Hitler's rise to power in Germany, the Austrian defence measures had to face a much longer-lasting state of emergency than would have been necessary when Papen's measures had been implemented.

3.2.1.3. Predominance of Catholicism in Austria. Whereas in Germany, at least on national and on Prussian State levels, Catholics and their thinking had always been a minority within the Protestant majority ${ }^{248}$, the situation in Austria was the complete opposite: The Catholic Church had always been predominant, in the $S t_{a} e^{249}$ as well as in society ${ }^{250}$ (at least apart from academia $^{251}$ ) and as a percentage of the population. ${ }^{252}$ This also meant that in Austria the ideas

${ }^{246}$ This is even admitted by Kreisky (1986/1995) 210.

${ }^{247}$ It may well be that Dollfuß was urged by the Italian prime minister (and leader of the Fascist movement) of the time, Benito Mussolini - to whom Dollfuß relied for protection against Hitler's Germany - to take action against the Social Democrats (see Wohnout [2014] $60 \mathrm{ff}, 68 \mathrm{f}$ ). The crushing of this party in February 1934, however, was not due to this Italian pressure, but only an inevitable consequence of the rebellion started by parts of the - at that time already illegal (see supra fn 168) - Social Democrats' armed forces (not only without any order from the party leaders, but even against their own clear orders, cf Reisberg [1974] 1, 4) on 12 February 1934 ('Schutzbundaufstand'). In this regard, Wohnout (ib, 69) reports that in January 1934 Dollfuß was still resisting the voices in his entourage encouraging him to crush the Social Democrats fearing that in this case frustrated Social Democrats would then join the NS (this assessment was quite accurate, cf. Kreisky [1986/1995] 206 f, 214).

${ }^{248}$ Furthermore, v. Schuschnigg (1938) 161, gives the impression that this minority position had indeed already led to a certain amount of accommodation, German Catholics consequently resenting the Austrian 'baroque Catholicism' of the time.

${ }^{249}$ Still in the first Austrian Republic, the Archbishop of Vienna, Theoror Innitzer (Archbishop since 1932; Cardinal since 1933) had previously been a minister in the federal government (1929/30.); on the other hand, a prelate, Ignaz Seipel, had been not only leader of the Catholic party (1921-1930), but in autumn 1918 for some weeks a member of the last imperial government and subsequently several times head of the federal government (1922-1924; 19261929).

${ }^{250}$ Until 1938 the law on marriage was taken from the various religious communities, meaning that for all Catholics - the vast majority (see next fn but one) - the Canon law applied; in addition, a multitude of Catholic associations existed, cf. Hanisch (1994) 293.

${ }^{251 ،}$ 'Catholica non leguntur' (See supra fn 1).

${ }^{252}$ More than $80 \%$, cf. Hanisch (1994) $214 \mathrm{f}$. 
for a Catholic alternative to modern parliamentary democracy, based on ecclesiastical concepts $^{253}$, in particular on the Encyclica 'Quadragesimo Anno' ${ }^{254}$, were much more elaborated than the German corollary of the 'New State'. ${ }^{255}$

3.2.1.4. The obstacles to a restoration of the monarchy in Austria. Whereas in Bavaria the heir to the Crown, Prince Rupprecht, had been a highly respected (Bavarian and Prussian) field marshal during World War I and whereas also on national (and Prussian) levels there existed, at that time, at least workable options (either Emperor and King Wilhelm II himself, or Crown Prince Wilhelm, himself also a general in World War $\mathrm{I}^{256}$, or one of his sons ${ }^{257}$ ), the situation in Austria was - despite a very strong legitimistic movement - much less favourable:

- On the one hand, the territory now forming the Republic of Austria had never formed a monarchical unity so that the choice of an appropriate title would already have posed problems. $^{258}$

- On the other hand, the heir to the throne of the former Austrian(-Hungarian) Empire, Archduke Otto, was only born in 1912 and, thus, would already due to his youth ${ }^{259}$ not yet have been a fully convincing alternative. ${ }^{260}$

- Thirdly, given the double failure of the attempts of Otto's father, Emperor Charles, to restore his rule (as king) in Hungary not least due to international protests (in particular from Czechoslovakia, but also from Romania and Yugoslavia, the 'small entente', and finally backed

${ }^{253}$ See in more detail Hanisch (1994) $315 \mathrm{f}$.

${ }^{254} \mathrm{cf}$. Hanisch (1994) 303, 317, here citing Rudolf Count Hoyos, then president of the Parliament ('Bundestag'); see, however, also Reisberg (1974) 150 and Tálos (2013) 87. Tálos, however, holds that the Constitution 1934 misinterpreted the Encyclica when assigning to the 'professional estates' the quality of State institutions instead of mere members of civil society. Whereas a proper answer would require a separate contribution (also taking into account the similar, but much better elaborated remarks of Isensee [2001], 27 f), I restrict myself to the following

(i) even in contemporary Austria the successors of these professional estates are located, by Articles 120a f of the B-VG, on both sides of the borderline, combining the task of representing particular interests vis-à-vis the State with the carrying out of functions as administrative bodies of the State

(ii) the whole distinction between State and civil society is a modern one, a consequence of the monopoly of power achieved by the absolute monarch, and does not fit into more traditional concepts of society such as, among others, does the Catholic Social Teaching still deeply rooted in medieval thinking.

${ }^{255}$ See supra text by fn 82 .

${ }^{256}$ As is well-known, there had indeed been plans to put forward Wilhelm as candidate for the national presidential elections in 1932 .

${ }^{257}$ Prince Wilhelm (born 1906) or Prince Louis Ferdinand (born 1907); see already supra fn 83.

${ }^{258}$ The most appropriate title being that of a 'kingdom' one would have had to go back to the project agreed on (but never implemented) by Emperor Frederic II (Hohenstaufen) and Duke Frederic II (Babenberg) in 1245.

${ }^{259}$ In contrast to his German counterpart, Wilhelm (see right supra fn 256), Otto would not have been qualified to stand for election as Federal President of the Republic, Article 60 (3) B-VG requiring a minimum age of 35.

${ }^{260}$ In Austria, memories of the beginning of the reign of Emperor Francis Joseph - who had succeeded to the throne in December 1848 when only 18 years old and had already lost Austria's predominant position in Europe in his first few years (in 1856, 1859 and 1866) - were then still fresh, as were memories of the rather weak performance of the last Emperor Charles who, although already 29 years old when becoming monarch, was still considered to be 'young' (compared not only with old Francis Joseph but also with the very dominant personality of Archduke Francis Ferdinand, assassinated in 1914, then heir to the throne). 
by France and by the United Kingdom ${ }^{261}$ ), restoration of Habsburg ${ }^{262}$ rule in Austria, even as a tool against Hitler ${ }^{263}$ would have been much more complicated than a comparable restauration of the respective former dynasty in Germany or in any one of the German federated States.

So in fact it was no longer important in the Austrian case that Dollfuß, most probably ${ }^{264}$ shared the self-confidence of Bavaria's prime minister Held who was not really inclined to subordinate himself to a monarch ${ }^{265}$ - in contrast to the genuine monarchist Papen.

3.2.2. The solution. On the fundamental level, Dollfuß found a classical answer to Hitler, expressed in the preamble to the Constitution of 1 May 1934 where we read that it is 'Almighty God from whom all law emanates'. By this small statement Dollfuß

- firmly contradicted the NS principle that it is the will of the mortal 'Führer ${ }^{266}$ which is supreme ${ }^{267}$

- made clear that the State is founded on 'law', not on sheer power (violentia) as such.

From an emotional perspective one may doubt whether this principle, lacking the traditional combination with the monarchy (based on the 'Grace of God') could then really have sufficed. From a principal perspective, however, Dollfuß had, by this formula, found and expressed in a purely rational way the essence of the decisive difference between human 'fascism' and the 'rule of transcendent 'law'.

\footnotetext{
${ }^{261}$ See in more detail e.g. Sakmyster (2006) $97 \mathrm{f}$.

${ }^{262}$ Strictly speaking, the name of the dynasty would have been 'Habsburg-Lothringen' or, even more correctly, 'Austria'.

${ }^{263}$ Nevertheless, Otto was still perceived by Hitler as the main Austrian 'enemy' in 1938: the plan for the military occupation implemented on 12 March was named 'Unternehmen Otto', and on 20 April 1938 an arrest warrant was issued against Archduke Otto for high treason (see Kindermann [2010/2012], $101 \mathrm{f}$, in particular $104 \mathrm{f}$ ); opinions that the 'Unternehmen Otto' referred to emperor Otto I (912-973) exist, but seem to be farfetched and to reflect the fact that the plan to invade the Soviet-Union (finally: 'Barbarossa') was first, in 1940, also labelled 'Otto' - maybe to conceal, post factum, the importance Hitler still had attributed to Archduke Otto in 1938.

${ }^{264}$ In his speech of 1 May 1934 promulgating the Constitution 1934 (see E. Weber [1935] 223 f, 238; translation into English by A.B.) Dollfuß stated that from now on 'under the authoritarian leadership of the Chancellor experienced men ... would guide Austria' and, in an even more normative way: 'The whole leadership resorts to the Chancellor who in turn is appointed by the Federal President. .... This self-confidence of the head of government could have fit with a purely ceremonial role for a monarch, not however, with a more active understanding of monarchical responsibility as Archduke Otto was also very likely to feel still bound to (indeed, as is well-known, Otto would request in February 1938 to be appointed Chancellor himself - not Regent, although also this could have been done quite easily by applying the 'Enabling Act' of 30 April 1934 [see supra subsection 3.1.2.3]).
}

${ }^{265}$ See supra fn 121.

${ }^{266}$ Nevertheless, Hitler had assumed pseudo-religious status as a 'salvator populi a Deo missus' (and as such even been recognized by the German Crown Prince Wilhelm [!!], see Bracher (1964) $118 \mathrm{ff}$ ) - obviously a severe challenge for Christians, in particular for the Catholic Church. For the full implications of the position of the 'Führer' see Schmitt (1934) $946 \mathrm{f}$; Wacke (1944), $273 \mathrm{f}$, in particular $278 \mathrm{f}$.

${ }^{267}$ That this message of the Constitution 1934 (which may have been advised by the former federal chancellor and minister for the army Carl Vaugoin who had demanded such a constitutional provision back in May 1933; see Staudinger [1071] 348 f) was indeed understood by friends and enemies can be inferred from the famous statement the Archbishop of Vienna, Innitzer, made in October 1938, already under NS domination, addressing himself to the Catholic youth: 'Christus is your leader' - which was answered by a storming of the Bishop's Palace by NS youth (see Fritz/Handl/Krause/Taus [1988] 27 f). 
Also on the tactical level, Dollfuß focused more clearly than Article 48 of the Weimar Constitution, or even later Loewenstein, on what was decisive in hindering Hitler's rise to power: not so much the suspension of classical fundamental rights (liberty, security; home; property; opinion, assembly, association, communication) which were all provided in principle by the Constitution $1934^{268}$ but of the right to political participation - a position which again implies a commitment to the 'rule of law' even in cases in which political participation cannot be preserved, hence - if a choice needed to be made - a clear preference for the 'rule of law' over the maintenance of 'democracy'. ${ }^{269}$

Even the supplement - the temporary authorization of the government to unlimited legisla$\operatorname{tion}^{270}$ - does still fit in this picture: exactly due to the fact that this authorization was to be terminated by the implementation of crucial parts of the new Constitution we realize here exactly that sort of dictatorship which Carl Schmitt had labelled 'commissarial' ${ }^{271}$, i.e. destined not to quit permanently the rule of law, but to re-establish regular conditions ${ }^{272}$ - although, on technical level, this aim (teleology) was not enshrined clearly enough: otherwise, exactly this provision, deemed to restore the full rule of law, could not have been used for its most complete abolition. ${ }^{273}$

3.2.3. The classification against the background of Loewenstein's 'militant democracy'. Obviously, the measures implemented by Dollfuß (whether lawful from the perspective of the B-VG or not) coincided with Loewenstein's intention insofar as they effectively delayed the NS rise to power in Austria - originally envisaged for the first half of 1933, to be in lockstep with the takeover in the German federated states ${ }^{274}$ - until March 1938.

${ }^{268}$ Obviously each of these rights had its limitations, the texts of which, however, do not exceed what we still read in the limitation clauses of modern human rights instruments.

${ }^{269}$ It is noteworthy that by making this clear preference Dollfuß and his Constitution 1934 did not leave the ground of the tradition also enshrined as the 'fundamental order', in the B-VG (see supra fn 218). Nevertheless, Pelinka (2014) 119, raises the question of whether rule of law without democracy could ever exist and answers: 'When man den Rechtsstaat auch unter dem Gesichtspunkt der liberalen und individuellen Grundrechte sieht, so kann es keinen nichtdemokratischen Rechtsstaat geben.' This statement (by a political scientist) is, obviously, only correct when the notion 'liberale und individuelle Grundrechte' is understood in Pelinka's peculiar way, i.e. not only including 'die zentralen liberalen politischen Grundrechte' as such, but, not in the least self-evident (in particular under the label 'liberal'!), also egalitarian voting rights. In this latter case, however, no legal order in the $19^{\text {th }}$ Century, including Austria under the December Constitution (part of which had formed the StGG 1867/142!), could be considered a 'Rechtsstaat', nor could the concepts of the very reformulators of this idea at the beginning of that century, Robert v. Mohl and others (see Wiederin [2014] $88 \mathrm{f}$ ) - a rather absurd consequence.

${ }^{270}$ See supra text after fn 238.

${ }^{271}$ See supra fn 49.

${ }^{272}$ For the future, Dollfuß was apparently of the opinion that the enlarged emergency provisions of the new Constitution (in particular Art 148 which also allowed, if necessary, deviation from constitutional law, insofar as the essence of the Constitution was preserved) would suffice.

${ }^{273}$ In fact this authorization gave license to unlimited legislation (in particular due to the abolition of Article 44 [2] B-VG having required a referendum for fundamental changes by BGBl $1934 \mathrm{I} / 255$; see supra fn 231) and may, therefore, be considered as resorting temporarily to the full power of a sovereign (even in this case, however, not with the aim of creating a new order, but as an ultimate means to safeguard the already existing order). Such a limited understanding is supported by the fact that the Federal President of the time, (still) Wilhelm Miklas, preferred to resign from office rather than to sign the 'Reunification Act' (see supra fn 241).

${ }^{274} \mathrm{cf}$. Wohnout (2014) $56 \mathrm{ff}, 63$. 
The measures - culminating in the oktroi of a fully-fledged constitution, based on the concept of the radical supremacy of the rule of (Divine) law - transcended, however, by far the somewhat simplistic advice of Loewenstein to just apply (even preventively) the 'ius talionis' to 'fascists' (hence, it is not purely coincidental that Loewenstein's concept resembles more the Presidential Ordinance of 28 February $1933^{275}$ - with the sole difference being the addressees than the measures taken by Dollfuß or planned by Papen). In fact, Dollfuß' measures corresponded - from the perspective that the deeply rooted 'forma regiminis ${ }^{\text {'276 }}$, the 'rule of law', was more fundamental, at least in the Austrian constitution, than the only more recently introduced 'forma imperii' ${ }^{277}$, the 'principle of democracy' - much more to the analysis of Carl Schmitt of $1928^{278}$ that it was justified to suspend several constitutional provisions in order to preserve the essence of the constitution, i.e. the essence of the rule of law also in a state of emergency and with regard to the 'enemy'.

3.2.4. The assessment by Loewenstein himself. Loewenstein himself approved at least the original coincidence of Dollfuß' policy with his own concept when stating (in the context of ' $[\mathrm{s}$ ] ome Illustrations to Militant Democracy ${ }^{279}$ ):

'For a short while, between March, 1933, and February, 1934, the Austrian Republic seemed to take a similar course. The government of Dollfuss was at first intent on avoiding fascism as well as communism, and in May, 1933, it outlawed subversive movements of all kinds impartially. ${ }^{280}$

Loewenstein, however, continued:

'In February, 1934, however, Dollfuss ruthlessly crushed the Socialist party, which was intensely loyal to constitutional government, and established a one-party state, thus openly flouting the rule of law and turning Austria into a fascist country without even the pretext of constitutional government. The attempt of the dominating minority group to keep out national socialism by a pitiful imitation of its emotional propaganda ${ }^{281}$ seems doomed to failure. ${ }^{, 282}$

\footnotetext{
${ }^{275}$ See supra fn 50 and subsection 2.4, first paragraph. For the similarity to the Bolshevist view see supra fn 52 .

${ }^{276}$ See supra fn 35 .

${ }^{277}$ See supra fn 35 .

${ }^{278}$ See supra fn 49.

${ }^{279}$ Cit Loewenstein (1937) 638 (see already supra the introduction to section 2).

${ }^{280}$ Cit Loewenstein (1937) 640.

${ }^{281}$ Such tendencies ('überhitlern') - with the clear view of 'keeping out' the NS! - did indeed exist, see Hanisch (1994) 304, fn 58; Wohnout (2014) 69. Although one might very well dispute the efficacy (Dollfuß himself was rather sceptical, see Wohnout, ib), it is striking that it was only Loewenstein - himself advocating that fascism 'be checked' and 'by a similar technique' (see supra text at fn 10) - who criticized this 'attempt'(!).

${ }^{282}$ Cit Loewenstein (1937) 640.
} 
Most unfortunately, Loewenstein did not provide any evidence or sources for the facts underlying his assessment. ${ }^{283}$ So one can only state that the basis of Loewenstein's assessment was inaccurate in several respects:

- Dollfuß did not 'ruthlessly' 'crush' an 'intensely loyal'284 'Socialist party', but was forced to react effectively to the rebellion of the (already illegal ${ }^{285}$ ) armed forces of the Social Democrats ${ }^{286}$ in

${ }^{283}$ This lack of evidence is no particularity of this specific part but a general characteristic of the whole article. This deficiency is, however, in particular felt with regard to these events here at issue because they happened at a time when Loewenstein was no longer at the scene (cf., in contrast, the situation mentioned in $\mathrm{fn} 58$ ), but far away in the USA and had to rely on information which one would have liked to know in order to assess its accuracy.

${ }^{284}$ When one of the leading Austro-Marxists of the time, Max Adler, wrote (1922) 197, (emphasis added): 'Solange ein Staat durch ökonomische Klassengegensätze gespalten ist, hat er eben bei noch so demokratischem Wahlrecht keine Volksvertretung, weil es ein solidarisches Volk in ihm nicht gibt. In den Formen der parlamentarischen Selbstbestimmung vollzieht sich dann immer noch bloß ein Stück des Klassenkampfes. Und die demokratische Parlamentsmehrheit ist im Klassenstaate stets Machtwille der die Majorität kommandierenden Klasse ...., announced that fundamental rights as freedom of the press, of assembly, of association would be limited or even cancelled with regard to the members of the overthrown classes (ib, $192 \mathrm{f}$ ), and even spoke of 'annihilation' (see supra fn 54), one is entitled to doubt whether this loyalty did in fact ever exist.

Nevertheless it is true that before February 1934 Dollfuß had maintained contacts with some Social Democrats (cf. Berchtold [1998] 748 f), in particular to Karl Renner who

(i) not only on 26 October 1933 presented a proposal for a authoritarian reform of the B-VG - apparently close to what had already been in force during the implementation of the Geneva loan (see Kohl [2018] $318 \mathrm{f}$, in particular $321 \mathrm{f}$, for the Act BGBl 1922/844); cf. Jabloner [2014] 109)

(ii) but had also, about the same time, elaborated an even much more far-reaching proposal (already close to the Constitution 1934 (see Jabloner, ib, 109 f).

${ }^{285}$ The armed forces of the Social Democrats ('Schutzbund') - not the party as such - had already been prohibited, on 30/ 31 March 1933 - not, however, so much as an end in itself but as a means to enhance the government's credibility when fighting the NS (see Kindermann [1984] 105). In fact this prohibition was scarcely enforced, otherwise the insurgence of February 1934 would have lacked the capacity (Hanisch [1994] 305, even reports that the 'Schutzbund' was armed 'frantically' from Czechoslovakian territory after having been prohibited).

${ }^{286}$ It may be only a detail, but one apt in particular to assess Loewenstein's accuracy as well as the sources of his information (cf. supra fn 283): The correct denomination of the SDAP ('Sozialdemokratische Arbeiterpartei'), i.e. the party here at issue, was at the relevant point in time not (yet) the 'Socialist Party', but the 'Social Democrats'. It was only after the events of February 1934 that one former faction of the party, the 'Revolutionary Socialists' (cf. Kreisky [1986/1995] 156) arose as a de facto independent entity which, in April 1945, formed, together with the former Social Democrats, the new 'Socialist Party' (SPÖ; renamed the 'Social Democrats' in 1991). 
February $1934^{287}$ - not least with regard ${ }^{288}$ to the fact that his overarching aim remained to prevent similar actions by the NS. ${ }^{289}$

- He certainly did not aim to 'turn Austria into a fascist country without even the pretext of constitutional government' - which is apparent from the very existence of the Constitution 1934 (which is not even mentioned by Loewenstein!) as such. ${ }^{290}$

${ }^{287}$ This eventual rebellion (not approved at all by the central party leaders, see supra fn 247 ) marks the decisive (double) difference from the 'Preußenschlag' in Berlin in 1932: in Austria, the regional government of Vienna led by the Social Democrats was only removed after the armed rebellion, whereas the German Social Democrats did not even dispose of armed forces of their own (they supported, together with the Catholic Party and other smaller groups, the so-called 'Reichsbanner Schwarz-Rot-Gold') and, thus, strictly stuck to a policy of 'legality'.

${ }^{288}$ There was, however, already a doubtful prelude to the rebellion of February 1934 (which, most probably, worked in favour of the rapid and effective action of the government, too): the riots of July 1927 triggered by the jury's verdict of acquittal in the so-called 'Schattendorf -trial. There, a furious mob, incited by the editor in chief of the 'ArbeiterZeitung' (the official medium of the Social Democrats), Friedrich Austerlitz (then also a member of the Constitutional Court!!), supported by Social Democrat Viennese municipal employees who either called a general municipal transport services strike (Schuschnigg) or just switched off electricity for the tramway (Konrad) and by the Social Democrat mayor of Vienna Karl Seitz who refused to call for support from the army in time, resulted in

- the destruction of the very symbol of the rule of law in Austria, the Palace of Justice, and

- in a fairly high number of deaths (89 rioters and 5 policemen) and in even more (above 1000) persons seriously injured. Far from assuming fundamental responsibility (although, it is true, some Social Democrats, including the former army general and latter Federal President Theodor Körner had tried to calm down the masses) the Commander of the Viennese Police (Johannes Schober, twice head of the federal government) who was responsible for the police action and the final defeat of the rioters was denounced by Social Democrats as the 'assassin of the workers' (see v. Schuschnigg [1938] 104 f; Reisberg [1974] 121 f; Kindermann (1984) 91 f; Konrad [2017]; Leser (1988) 35 f; Hanisch [1994] 286, 288 f).

How close the two incidents (the first of which Loewenstein failed to mention) were interconnected is shown by

- the amazingly low number of losses, in particular on the side of the insurgents in February 1934: during this countrywide and armed rebellion about 112 members of the governmental armed forces, but roughly only the same number of members of the rebelling forces and again roughly the same number of civilians were killed in or on the occasion of action, see [https://de.wikipedia.org/wiki/Februark\%C3\%A4mpfe_1934\#cite_note-Bauer74-12] - apparently due to the lessons learned before, i.e. the - this time - immediate (see Reisberg [1974] 6, $10 \mathrm{f}$ ), but apparently most considerate deployment of the federal army

- the epitheton ornans conveyed by Social Democrats in February 1934 to chancellor Dollfuß ('Arbeitermörder') - which entailed no proper judgement of the new facts but was, as said, simply transferred from Schober in July 1927 to Dollfuß in February 1934, being particularly unfair with regard to the latter who had, as shown, kept the number of dead 'workers' (despite the fact that, this time, they were armed) amazingly low (apparently at the expense of the government's forces who suffered almost the same number of losses as the insurgents).

${ }^{289}$ For NS terrorist action in 1932 as well as in 1933 in Austria, see Wohnout (2014) 55 ff. In particular regarding the principle of equal treatment placed at the very centre of the rule of law the Austrian government could not tolerate, on the one hand, an armed rebellion by Social Democrats when on the other hand aiming to prevent the NS movement from enacting exactly the same kind of violent acts. This reasoning also implied the use of the death penalty (for high treason or similar charges) with regard to Social Democrats: here, too, this most probably was an effective and credible deterrent with regard to the NS which played a decisive role, in particular against the background of the Potempa-case (see Bracher (1964) 619 f) where five NS activists had been sentenced to death by a court in Silesia for having murdered a Communist (on 9/10 August 1932), but (i) had their sentence commuted to life imprisonment by the Papen government and (ii) were finally released, only some months later (on 23 March 1933), by Hitler's government.

${ }^{290}$ This finding remains true even though the Constitution 1934 was never fully implemented (see supra fn 239). 
- On his way towards this Constitution 1934, Dollfuß may have 'flouted' the letter of the Constitution 1920/29 then in force, but certainly not the 'rule of law'. On the contrary, the formal breach of the B-VG was designed to preserve its very essence: precisely the rule of law - and thus exactly the same principle recommended by Loewenstein himself (despite his somewhat misleading wording, taking 'democracy' for the 'rule of law ${ }^{\text {'291 }}$ ).

- Finally, also the assessment of Austria as a 'one-party-State' can be disputed: in sharp contrast to Hitler (but also to Lenin), Dollfu $\beta$ did not simply forbid any other party except his own, but dissolved his own party, too, aiming to replace the party system as such by an aliud: the Patriotic Front. ${ }^{292}$

When combining Loewenstein's initial assessment and the demonstrated flaws in the basis of his assessment for the period after February 1934, is it not reasonable to presume that Loewenstein, after having corrected these flaws (which were, besides, all committed not only in a field outside his own core competence, but also under circumstances in which he did not have easy access to reliable first-hand information) would have come to the conclusion that the subsequent measures taken by Dollfuß, the oktroi of the constitution 1934 included, also met his own criteria of 'militant democracy'?

\section{CONCLUSION}

\subsection{Historical}

The suspension of democracy in Austria from March 1933 onwards enacted by Dollfuß

- can only be understood properly when put into the context of

- failed German attempts, mainly of Catholic origin, to suspend democratic procedures by using emergency powers on the national as well as on the federated state level (Prussia; Bavaria) against the rising NS movement

○ the stupendous efficacy by which Hitler, after his rise to power, applied precisely those emergency tools his adversaries did not dare to use against him against not only Communists, but also against Social Democrats and - even much more important from Dollfuß' perspective - against Catholics.

- spared not only Austria five years of NS dominance, but thus also delayed to exactly this extent NS dominance over Europe ${ }^{294}$ - thus most probably laying the ground for final defeat of NS in 1945. From this perspective, the resistance of Dollfuß is by no means the least cause for the restoration of the 'rule of law' in contemporary Europe - as enshrined in Article 3 SCE as well as in Article 2 TEU - based on the conviction that a fundamental layer of 'inalienable' norms or principles is not at human disposal at all.

\footnotetext{
${ }^{291}$ See supra fn 23.

${ }^{292} \mathrm{cf}$. Berchtold (1998) $749 \mathrm{f}$.

${ }^{293}$ See the quotation supra at the end of fn 23.

${ }^{294}$ As Theo Habicht, leader of the Austrian NS, had put it already as early as 1932: 'Austria is the key in the core of Europe. Who is in the possession of Austria, dominates Central Europe' (see Hanisch [1994] 319; translation into English by A.B.).
} 


\subsection{Dogmatical}

The theoretical concept of 'militant democracy' coined by Loewenstein reflects - via the practical, although failed plans of (in particular) Papen and Held familiar to Loewenstein ${ }^{295}$ nothing but the traditional - mainly ${ }^{296}$ Catholic - position that the fundamentals of rules governing human individual and societal life are not at human disposal, but enshrined in Divine (and natural) law, a position which, however, can also be derived from the father of modern State sovereignty, Jean Bodin. ${ }^{297}$ It was precisely this position which was - after having been denied by the positivism of the $19^{\text {th }}$ century - again given precise expression in the preamble to the Austrian Constitution of 1 May 1934 and gained, only shortly afterwards and in the same context of overcoming NS, world-wide ground, as the Charter of the UN, the UDHR and sub-sequent human rights documents show ${ }^{298}$, also and in particular with regard to international criminal $\operatorname{law}^{299}$ and, not least, the general concept of an international 'ius cogens' taking precedence even over national or international state treaty law. ${ }^{300}$

In sharp contrast to Karl Loewenstein's misunderstanding of this position (as well as to his quite doubtful vicinity to St. Just, Bucharin and Carl Schmitt's dichotomy ${ }^{301}$ ), however, it has to be emphasized that this concept (of the Austrian Constitution 1934 as well as of current international law) is a concept of the 'rule of law' and, thus, the natural opposite of all concepts based on sheer submission to force. So even enforcing the necessary respect for the rule of law may never amount to a simple assimilation to 'fascism' as advocated indeed by Loewenstein.

${ }^{295}$ Most unfortunately, for the aforementioned reasons Loewenstein did not take into account the Austrian Constitution of 1 May 1934.

${ }^{296}$ Also the German Social Democrats' conviction (underlying, at least partly, the attempts of the Prussian government led by Otto Braun), however, might ultimately have been rooted in a comparable belief in the existence of supra-positive natural law (cf. Bernstein [1923] $11 \mathrm{ff}$, in particular with regard to the sources of pre- and non-Marxist socialism, even of Karl Liebknecht's views [ib, 30, 35]).

${ }^{297} \mathrm{cf}$. [1981]): 'That all monarchs are subject to natural law is beyond any doubt'; translation into English by A.B.).

${ }^{298}$ In Lucerne, during a plenary session of the IVR Congress 2019 ('Human Dignity: Challenges, Controversies and Promise', Friday 12 July), one of the panellists, Heiner Bielefeldt, affirmed when asked by the author of this contribution, that in his (Bielefeldt's) view the value of 'human dignity' and other core human rights already mentioned in the UNC and further developed in the subsequent documents were indeed not at human disposal but stemmed from (a sort of) natural law.

${ }^{299} \mathrm{cf}$. Article 15 (2) ICCPR or Article 7 (2) ECHR which state in essence that national law is null and void insofar as it deviates from 'general principles of law recognized by the community of nations'/'by civilized nations' with regard to behaviour considered to be 'criminal' by these principles.

${ }^{300} \mathrm{cf}$. Article 53 VCLT.

${ }^{301}$ See supra (text by) fn 48 and seq. 
This finding implies in particular that even the most dangerous perpetrator may never be completely thrown out of the sphere of $\mathrm{law}^{302}$; because, as the Austrian Supreme Administrative Court put it in perhaps its most clamorous case:

'Es steht im Rechtsstaat kein Mensch über dem Recht und keiner außerhalb des Rechts'. ${ }^{303}$

\section{REFERENCES}

\section{MONOGRAPHIES}

Achenwall, G. and Pütter, J.St., Anfangsgründe es Naturrechts: Elementa Iuris Naturae (ed Jan Schröder, Insel Verlag 1995).

Adler, M., Die Staatsauffassung des Marxismus. Ein Beitrag zur Unterscheidung von soziologischer und juristischer Methode (1922 [reprint 1964] Wissenschaftliche Buchgesellschaft).

Anschütz, G., Die Verfassung des Deutschen Reichs vom 11. August 1919 (14 th edn, Georg Stilke 1933).

Aristoteles, Politics (Greek - English, ed Harris Rackham, Harvard University Press 1932/1944/2005).

Balthasar, A., Die österreichische bundesverfassungsrechtliche Grundordnung unter besonderer Berücksichtigung des demokratischen Prinzips. Versuch einer Interpretation (Springer 2006).

Balthasar, A., Absolute Nichtigkeit genereller Normen in der österreichischen Rechtsordnung (Verlag Sramek 2016).

Berchtold, K., Verfassungsgeschichte der Republik Österreich, Fünfzehn Jahre Verfassungskampf 1918 - 1933 (volume I [only volume], Springer Verlag 1998).

Bernstein, E., Der Sozialismus einst und jetzt. Streitfragen des Sozialismus in Vergangenheit und Gegenwart ( $2^{\text {nd }}$ edn, J. H. W. Dietz 1923).

Bodin, J., Sechs Bücher über den Staat (German translation by Bernd Wimmer, ed Peter Mayer-Tasch C.H. Beck 1981).

Bracher, K. D., Die Auflösung der Weimarer Republik (4th edn, Ring Verlag 1964).

Bracher, K., Sauer, W., \& Schulz, G., Die nationalsozialistische Machtergreifung. Studien zur Errichtung des totalitären Herrschaftssystems in Deutschland 1933/34 (Springer 1960).

${ }^{302}$ cf., in exactly this vein, also Bradley/Ewing (2011) 90: 'However lawless may have been the acts of the IRA, ... government must not retaliate with measures which are not only not lawful but are of such a nature that it would be impossible on moral ... grounds to make them lawful', and, even more recently, Jesse (2019) 14 (emphasis added): ‘. . . die Demokratie darf sich niemals der Mittel ihrer Gegner bedienen.'

${ }^{303}$ Cit Judgement of 24 May 1963, No 0245/62, (VwSlg) No 6035/A, dealing with the right of Austria’s last Crown Prince, Archduke Otto (see already supra text after fn 257), to enter his home country: 'Under the rule of law nobody is above the law and nobody outside (of the) law.' (unofficial translation by A.B.). It is said that this famous sentence was coined by Hans Klecatsky, later professor of Constitutional Law, member of the Austrian Constitutional Court and (1966-1970) Austrian federal minister for Justice. Hence, see for his understanding of the rule of law (also and in particular with regard to its relationship to the principle of democracy) Klecatsky (1967), on p $14 \mathrm{f}$, referring also to the famous judgement cited here. 
Bradley, A., \& Ewing, K., Constitutional and Administrative Law (15th edn, Pearson Education Limited 2011).

Brauneder, W., Österreichische Verfassungsgeschichte (11th edn, Verlag Manz 2009).

Fritz, H., Handl, R., Krause, P., \& Taus, G., Farbe Tragen, Farbe bekennen 1938 - 1945, Katholisch Korporierte in Widerstand und Verfolgung (Österreichischer Verein für Studentengeschichte 1988).

Hacke, J., Existenzkrise der Demokratie. Zur politischen Theorie des Liberalismus in der Zwischenkriegszeit (Suhrkamp - Insel Verlag 2018).

Hanisch, E., Der lange Schatten des Staates. Österreichische Gesellschaftsgeschichte im 20. Jahrhundert (Ueberreuter Verlag 1994).

Heiber, H., Goebbels-Reden (Verlag Droste 1971).

Heidegger, M., Platons Lehre von der Wahrheit. Mit einem Brief über den Humanismus $\left(2^{\text {nd }}\right.$ edn, Francke Verlag 1954).

Huemer, P., Sektionschef Robert Hecht und die Zerstörung der Demokratie in Österreich. Eine historischpolitische Studie (Verlag für Geschichte und Politik Wien 1975).

Hobbes, T., Leviathan, or The Matter, Forme, \& Power of a Common-Wealth Ecclesiasticall and Civill (ed. Crawford Macpherson 1968, 1980 Penguin Books).

Isensee, J. Subsidiaritätsprinzip und Verfassungsrecht. Eine Studie über das Regulativ des Verhältnisses von Staat und Gesellschaft ( ${ }^{\text {nd }}$ edn with a supplement: Die Zeitperspektive 2002. Subsidiarität - das Prinzip und seine Prämissen (Duncker \& Humblot 2001).

Isensee, J., Das Volk als Grund der Verfassung: Mythos und Relevanz der Lehre von der verfassunggebenden Gewalt (Springer Verlag 1995).

Jung, O., Plebiszit und Diktatur: die Volksabstimmungen der Nationalsozialisten (Mohr Siebeck 1995).

Kant, I., Zum ewigen Frieden und Auszüge aus der Rechtslehre (ed. Oliver Eberl and Peter Niesen, indication of pages according to the 'Academy edition' Suhrkamp 2011).

Kant, I., Metaphysische Anfangsgründe der Rechtslehre. Metaphyik de Sitten Erster Teil (ed. Bernd Ludwig, indication of pages according to the 'Academy edition', 3rd edn, Felix Meiner 2009).

Kelsen, H., Froehlich, G. and Merkl, A., Die Bundesverfassung vom 1. Oktober 1920 (Franz Deuticke 1922).

Kindermann, D., Die Habsburger ohne Reich. Geschichte einer Familie seit 1918 ( $2^{\text {nd }}$ edn, Verlag Kremayr \& Scheriau KG 2010/2012).

Kindermann, G., Hitlers Niederlage in Österreich. Bewaffneter NS-Putsch, Kanzlermord und Österreichs Abwehrsieg 1934 (Hoffmann und Campe Verlag 1984).

Kluckert, S., Zuwendung und Gesetz insbesondere zu Grund und Grenzen der Außenwirkung von Haushaltsgesetz und Haushaltsplan (Mohr Siebeck 2018).

Kreisky, B., Zwischen den Zeiten. Erinnerungen aus fünf Jahrzehnten (Siedler 1986/1995).

Kustatscher, E., Berufsstand oder Stand? Ein politischer Schlüsselbegriff im Österreich der Zwischenkriegszeit (Böhlau Verlag 2016).

Lenin, W.I., Staat und Revolution. Die Lehre des Marxismus vom Staat und die Aufgaben des Proletariats in der Revolution (reprint of the German translation of the second edition, $2^{\text {nd }}$ edn, Verlag Das Freie Buch 2012).

Leser, N., Salz der Gesellschaft. Wesen und Wandel des österreichischen Sozialismus (Orac Verlag 1988).

Locke, J., The Second Treatise. An Essay Concerning the True Original, Extent, and End of Civil Government, in: id, Two Treatises of Government (ed.Peter Laslett, Cambridge University Press 1960, 1965, 2008).

Mayer, H., and Muzak, G., B-VG. Kurzkommentar (5th edn, Manz Verlag 2015).

Mehring, R. and Schmitt, C., Aufstieg und Fall. Eine Biographie (C.H. Beck 2009). 
Mennen, K., Selbstinszenierung im öffentlichen Raum: Katholische und sozialdemokratische Repertoirediskussionen um 1930 (Waxmann 2013).

Poetzsch-Heffter, F., Handkommentar der Reichsverfassung vom 11. August 1919 (3rd edn, Liebmann 1928).

Popper, K., Die offene Gesellschaft und ihre Feinde I. Der Zauber Platons (8th edn, Mohr Siebeck Verlag 2003).

Quaritsch, H., Positionen und Begriffe Carl Schmitts (Duncker \& Humblot 1989).

Reisberg, A., Februar 1934. Hintergründe und Folgen (Globus Verlag 1974).

Schaunig, Ch., Frauen im Austrofaschismus - Rückschritt, Stillstand, Fortschritt? Eine Suche in der Stadt und auf dem Land, (master's thesis 2010), available online: https://core.ac.uk/download/pdf/11591417. pdf [accessed 5 November 2020].

Schmitt, C., Der Begriff des Politischen. Text von 1932 mit einem Vorwort und drei Corollarien (Duncker \& Humblot 1963).

Schmitt, C., Die Diktatur. Von den Anfängen des modernen Souveränitätsgedankens bis zum proletarischen Klassenkampf. Mit einem Anhang: Die Diktatur des Reichspräsidenten nach Art. 48 der Weimarer Verfassung ( $2^{\text {nd }}$ edn, Duncker \& Humblot 1928).

Sakmyster, T., and Horthy, M., Ungarn 1918 - 1944 (Edition Steinbauer German edition 2006).

Schmitt, C., Verfassungslehre (11th edn, Duncker \& Humblot 2017/1928).

Schmitt, C., Politische Theologie. Vier Kapitel zur Lehre von der Souveränität (Duncker \& Humblot 1921).

Schupmann, B., Carl Schmitt's State and Constitutional Theory. A Critical Analysis (Oxford University Press 2017).

Schuschnigg, K. v., Farewell Austria (Cassell \& Company Ltd 1938).

Tálos, E., Das austrofaschistische Herrschaftssystem. Österreich 1933-1938 (LIT Verlag 2013).

Weber, E., Dollfuß an Österreich. Eines Mannes Wort und Ziel (E. Reinhold Verlag 1935).

Weber, M., Politik als Beruf (1919, https://commons.wikimedia.org/wiki/Politik_als_Beruf\#/media/File: Max_Weber_-_Politik_als_Beruf_Seite_01.jpg accessed 21 November 2020).

Zarusky, J., Die deutschen Sozialdemokraten und das sowjetische Modell. Ideologische Auseinandersetzung und außenpolitische Konzeptionen 1917 - 1933 (Walter De Gruyter 1992).

Zenker, T., Österreich 1938. Hintergründe, Vorgeschichte und Folgen des 'Anschlusses' (2 ${ }^{\text {nd }}$ edn, Drehbuchverlag 2016).

Zeyringer, K., Gollner, H., Eine österreichische Literaturgeschichte seit 1650 (Studien Verlag 2012).

\section{CONTRIBUTIONS IN EDITED BOOKS}

Aretin, K.O. v., 'Der bayerische Adel. Von der Monarchie zum Dritten Reich' in: Broszat, M., Fröhlich, E., Großmann, A. (eds), Bayern in der NS-Zeit. Herrschaft und Gesellschaft im Konflikt Teil B (Walter De Gruyter 1981) 513 - 68.

Balthasar, A., '100 Jahre B-VG - eine komplexe Bilanz' in Balthasar, A. and Vincze A. (eds), Hundert Jahre österreichisches Bundes-Verfassungsgesetz. Die Perspektive von außen (2021) 229-317.

Balthasar, A. and Pichler, J., 'Interdependence between Fundamental Rights and institutional Law of the European Union' in Pichler, J. and Balthasar A. (eds), The Report on the Future of Europe - Striking the Balance between 'Unity' and 'Diversity'? Proceedings of the Conference on European Democracy 2013 (nwv 2014) $93-164$. 
Bezemek, Ch., 'Commentary on Article 54 EUCFR' in Holoubek, M. and Lienbacher G. (eds), Charta der Grundrechte der Europäischen Union. GRC-Kommentar ( $2^{\text {nd }}$ edn Manz 2019) 979-87.

Borowsky, M., 'Commentary on Article 54 EUCFR' in Meyer, J. (ed), Charta der Grundrechte der Europäischen Union (4th edn, Nomos 2014) 826-32.

Böckenförde, E.W., 'Der Begriff des Politischen als Schlüssel zum staatsrechtlichen Werk Carl Schmitts' in Böckenförde, E.W., Recht, Staat, Freiheit. Studien zur Rechtsphilosophie, Staatstheorie und Verfassungsgeschichte. (Erweiterte Ausgabe Suhrkamp 2006) 344-66.

Böckenförde, E., 'Die verfassunggebende Gewalt des Volkes - Ein Grenzbegriff des Verfassungsrechts' in Böckenförde, E., Staat, Verfassung, Demokratie. Studien zur Verfassungstheorie und Verfassungsrecht (Suhrkamp 1991) 90-112.

Cliteur, P. and Rijpkema, B., 'The Foundations of Militant Democracy' in Ellian, A. and Molier G. (eds), The State of Exceptions and Militant Democracy in a time of Terror (Republic of Letters Publishing 2012) 227-72.

Ellian, A. 'The State of Exception in a time of Terror' in Ellian, A. and Molier G. (eds), The State of Exceptions and Militant Democracy in a time of Terror (Republic of Letters Publishing 2012) 23-68.

Ernst, W., 'Politische Gewalt und bürgerliche Revolution' in Reinalter, H. (ed), Revolution und Gesellschaft. Zur Entwicklung des neuzeitlichen Revolutionsbegriffs (Inn Verlag 1980) 191-202.

Fister, M., 'Staatsnotstandrecht in Österreich' in Zwitter, A. (ed), Notstand und Recht (5th ed Nomos 2012) 160-196.

Grabenwarter, Ch., 'Geleitwort' in Zwitter, A. (ed), Notstand und Recht (5th ed Nomos 2012).

Heintze, H.-J., 'Völkerrechtliche Aspekte des Notstandsrechts' in Zwitter A. (ed), Notstand und Recht (5th ed Nomos 2012) 47-81.

Hong. Q.L., 'Democracy, Freedom of Speech and the Twin Challenges' in: Ellian, A. and Molier G. (eds), The State of Exception and Militant Democracy in a Time of Terror (Republic of Letters Publishing 2012) 329-366.

Hoppe, T., 'Commentary on Article 54 EUCFR' in Meyer J. (ed), Charta der Grundrechte der Europäischen Union (5th edn, Nomos 2019) 992-1008.

Jabloner, C., 'Wenigstens formale Kontinuität? Gescheiterte Bemühungen nach dem 4. März 1933' in: Parlamentsdirektion (ed), Staats- und Verfassungskrise 1933 (Böhlau 2014) 99-112.

Jabloner, C., 'Kann der Bundespräsident auf sein Amt verzichten?' reprinted in Olechowski, T. Zeleny K. (eds), in Jabloner C. (ed), Methodenreinheit und Erkenntnisvielfalt. Aufsätze zur Rechtstheorie, Rechtsdogmatik und Rechtsgeschichte (Manz Verlag 2013) 377-90.

Janistyn-Nowák, S., 'Vorwort' in Parlamentsdirektion (ed), Staats- und Verfassungskrise 1933 (Böhlau Verlag 2014) 7-15.

Klecatsky, H., 'Was verlangt der Rechtsstaat heute?' in Klecatsky, H., Der Rechtsstaat zwischen heute und morgen (Verlag Herder 1967) 13-31.

Konrath, Ch., 'Commentary on Art 29 B-VG' in Kneihs, B. and Lienbacher G. (eds), Rill-Schäffer-Kommentar (19. Delivery 2017).

Lepsius, O., 'Karl Loewenstein (1891 - 1973)' in Häberle P., Kilian, M. and Wolff H. (eds), Staatsrechtslehrer des 20. Jahrhunderts. Deutschland - Österreich - Schweiz (Walter De Gruyter 2015), 411-437.

Lienbacher, G., 'Commentary on Article 29/2, 3 B-VG', in Korinek et al (eds), Bundesverfassungsrecht (3. Delivery 2000).

Lindseth, P., 'Der europäische Kontext: Von der Krise der Zwischenkriegszeit zur Verfassungsregelung nach dem Krieg und darüber hinaus', in Parlamentsdirektion (ed), Staats- und Verfassungskrise 1933 (Böhlau Verlag 2014), 171-96. 
Molier, G., 'The State of Exception and Necessity under International Law', in: Ellian/Molier (eds), The State of Exception and Militant Democracy in a Time of Terror (Republic of Letters Publishing 2012) 177-225.

Möller, H., 'Preußen von 1918 bis 1947: Weimarer Republik, Preußen und der Nationalsozialismus' 149 316, in Neugebauer W. (ed), Handbuch der Preußischen Geschichte III Vom Kaiserreich zum 20. Jahrhundert und große Themen der Geschichte Preußens (Walter De Gruyter 2001).

Pelinka, A., 'Kommentar zum Panel 'Demokratiekrise und Staatsentwürfe', in Parlamentsdirektion (ed), Staats- und Verfassungskrise 1933 (Böhlau Verlag 2014), 113-22.

Randelzhofer, A. and Nolte, G., 'Commentary on Article 51 UNC' in Simma B. et al (eds), The Charter of the United Nations ( $3^{\text {rd }}$ ed 2012), 1397-1428.

Raschauer, B., 'Commentary on Art 29/1 B-VG' in: Korinek, K. et al (eds), Österreichisches Bundesverfassungsrecht (6. Delivery 2003).

Reiter-Zatloukal, I., 'Parlamentarismus im Fadenkreuz. Demokratiekonzepte und (Anti-) Parlamentarismus in Österreich 1918 bis 1933/34' in Parlamentsdirektion (ed), Staats- und Verfassungskrise 1933 (Böhlau Verlag 2014) 19-50.

Spanner, H., 'Die Entwicklung' in: Herbert Schambeck (ed), Das österreichische Bundes-Verfassungsgesetz und seine Entwicklung (Duncker \& Humblot 1980) 33-55.

Thiel, M., 'Militant Democracy and State of Emergency in Germany' Ellian, A. Molier, G. (eds), The State of Exception and Militant Democracy in a Time of Terror (Republic of Letters Publishing 2012) 273-327.

Weaver, C.K., Motion, J. and Roper, J., 'From Propaganda to discourse (and Back Again): Truth, Power, the Public Interest, and Public Relations' in L'Etang J. and Pieczka, M. (eds), Public Relations. Critical Debates and Contemporary Practice (Routledge 2006) 7-21.

Widder, H., 'Die Gesetzgebung' in Schambeck H. (ed), Das österreichische Bundes-Verfassungsgesetz und seine Entwicklung (Duncker \& Humblot 1980) 349-423.

Wiederin, E., 'Die Rechtsstaatskonzeption der Verfassung 1934. Zugleich Mutmaßungen über die Gründe einer Begriffsrenaissance' in Parlamentsdirektion (ed), Staats- und Verfassungskrise 1933 (Böhlau Verlag 2014) 75-97.

Wiederin, E., 'Das Recht des Staatsnotstands in Österreich' 5. ALES-Tagung 'Freiheit versus Sicherheit'. Proceedings (2016) 115-46.

Wohnout, H., 'Schritte auf dem Weg zur Diktatur. Die Entwicklung nach dem Ende des demokratischen Parlamentarismus im Spannungsfeld der deutschen und italienischen Österreichpolitik' in: Parlamentsdirektion (ed), Staats- und Verfassungskrise 1933 (Böhlau Verlag 2014) 51-74.

Wood, L., 'Commentary on Article 54 CFR' in: Peers, S., Hervey, T., Kenner J. and Ward A. (eds), The EU Charter of Fundamental Rights (Hart Publishing 2014) 1539-56.

\section{ARTICLES IN JOURNALS}

Balthasar, A., 'Internationaler Schutz im Wandel - vom II. Weltkrieg über den Ost-West-Konflikt zum Nord-Süd-Konflikt' (2017) JRP 214-39.

Hinghofer-Szalkay, St., 'Richterliche Rechtsnormvernichtung im Notstand' (2018) BRGÖ 357-70.

Hoogers, G., Karapetian, G., 'Federal disputes in the German Reich under the Weimar Constitution: Lessons in Dispute Settlement for the Kingdom of the Netherlands' (2018) ICL Journal 257-87. 
Loewenstein, K., 'Autocracy versus Democracy in Contemporaneus Europe I and II' (1935) APSC 571-593, 755-84.

Loewenstein, K., 'Militant Democracy and Fundamental Rights' (1937) APSR 417-432, 638-58.

Mikat, P., 'Zur Kundgebung der Fuldaer Bischofskonferenz über die nationalsozialistische Bewegung vom 28. März 1933' (1962) JCSW 209-35.

Raithel, Th. and Strenge, I., 'Die Reichstagsbrandverordnung. Grundlegung der Diktatur mit den Instrumenten des Weimarer Ausnahmezustands' (2000) VfZ 413-60.

Schmitt, C., 'Der Führer schützt das Recht. Zur Reichstagsrede Adolf Hitlers vom 13. Juli 1934' (1934) DJZ, 945-50.

Schölnberger, P., 'Durchaus erträglich?' Alltag im Anhaltelager Wöllersdorf (2010) 195 DÖW Mitteilungen $1-4$.

Staudinger, A., 'Bemühungen Carl Vaugoins um Suprematie der Christlich-Sozialen Partei in Österreich' (1971) MÖStA 1970 297-376.

Wacke, G., 'Staatsrechtliche Wandlung. Gedanken zur Verlängerung der Regierungsgesetzgebung' (1944) ZgS 273-303.

Braatz, W., 'Franz von Papen und die Frage der Reichsreform' (1975) PVS 319-40.

\section{COURTS}

International Court of Justice (CJ), Advisory Opinion of 9 July 2004, 'Legal Consequences of the Construction of a Wall in the Occupied Palestinian Territory'.

UN International Criminal Tribunal for the former Yugoslavia (ITY), Appeals Chamber, Judgement of 7 October 1997 (IT-96-22-A, Erdemovic).

European Court of Human Rights (CtHR), Judgement of 26 September 1995, ANo 17851/91, Vogt/G.

European Court of Human Rights (CtHR), Judgement of 22 March 2001, ANos 34044/96, 35532/97 and 44801/98, Streletz, Kessler, Krenz/G.

Austrian Constitutional Court (VfGH), Judgement of 30 june 1949, No B 299/48, Official Collection (VfSlg) No 1827.

Austrian Constitutional Court (VfGH), Judgement of 16 March 2001, No G 150/00, Official Collection (VfSlg) No 16.151.

Austrian Supreme Administrative Court (VwGH), Judgement of 24 May 1963, No 0245/62, Official Collection (VwSlg) No 6035/A.

German Federal Constitutional Court (BVerfG), Judgement of 22 May 1975, No 2 BvL 13, Official Collection (BVerfGE) 39, 334.

\section{OTHER SOURCES}

Austrian Center for Law Enforcement Sciences (ALES), Resilienz des Rechts in Krisenzeiten, of 23th December 2016, commanded by the Austrian Federal Ministry of the Interior, accessed 5 November 2020: https://bmi.gv.at/bmi_documents/2025.pdf. 
Jesse, E., Die offene Gesellschaft ist von vielen Seiten bedroht, - wer die Gefahren erkennen will, fährt immer noch gut mit Karl Popper, NZZ 2 August 2019, accessed 5 November 2020: https://www.nzz.ch/ meinung/karl-popper-heute-die-offene-gesellschaft-ist-vielfach-bedroht-ld.1491360? reduced $=$ true.

Konrad, H., 'Der Blick in den Abgrund', Kleine Zeitung, 2nd July 2017, accessed 5 November 2020: https:// austria-forum.org/af/Wissenssammlungen/Essays/Geschichte/Justizpalast-Brand_1927.

Parlamentsdirektion (ed) Staats- und Verfassungskrise 1933. Protokolle aus Nationalrat und Bundesrat (2014) accessed 5 November 2020: <https://www.parlament.gv.at/ZUSD/PDF/Verfassungskrise_1933_ Materialienband.pdf.

Weinberger, G, Sie verfolgen jeden mit Hasss, der nicht ihrer Meinung ist. Die islamistische 'Islamophobie'-Ideologie ist die Grundlage für das Verbrechen von Conflans, Die Presse, 23. 10. 2020, 27.

Wollenberg, J., 'Republik ist schon viel ...' Zur Wiederaneignung demokratischer Traditionen in der Erwachsenenbildung, Deutsches Institut für Erwachsenenbildung 2003, accessed 5 November 2020. https://www.die-bonn.de/doks/wollenberg0301.pdf .

Der Spiegel 15. 6. 2019, 'Wir müssen lernen, mutiger intolerant zu sein', accessed 5 November 2020: https:// www.spiegel.de/politik/joachim-gauck-wir-muessen-lernen-mutiger-intolerant-zu-sein-a-000000000002-0001-0000-000164407502.

https://de.wikipedia.org/wiki/Februark\%C3\%A4mpfe_1934\#cite_note-Bauer74-12 accessed 5 November 2020. https://de.wikipedia.org/wiki/Ludwig_Kaas accessed 5 November 2020.

https://austria-forum.org/af/Wissenssammlungen/Symbole/Faschismus_-_die_Symbole/Trabrennplatzrede_ 1933 accessed 5 November 2020.

https://austria-forum.org/af/Bilder_und_Videos/Historische_Bilder_IMAGNO/Dollfu\%C3\%9F\%2C_ Engelbert/00623702 accessed 5 November 2020.

https://www.historisches-lexikon-bayerns.de/Lexikon/Uniformverbot_1930-1932, accessed 5 November 2020. 